\title{
Unravelling the effects of cultural differences in the online appraisal of hospitality and tourism services
}

Article

Accepted Version

Creative Commons: Attribution-Noncommercial-No Derivative Works 4.0

Mariani, M., Borghi, M. ORCID: https://orcid.org/0000-00024150-1595 and Okumus, F. (2020) Unravelling the effects of cultural differences in the online appraisal of hospitality and tourism services. International Journal of Hospitality Management, 90. 102606. ISSN 1873-4693 doi: https://doi.org/10.1016/j.ijhm.2020.102606 Available at https://centaur.reading.ac.uk/91526/

It is advisable to refer to the publisher's version if you intend to cite from the work. See Guidance on citing.

To link to this article DOI: http://dx.doi.org/10.1016/j.ijhm.2020.102606

Publisher: Elsevier

All outputs in CentAUR are protected by Intellectual Property Rights law, including copyright law. Copyright and IPR is retained by the creators or other copyright holders. Terms and conditions for use of this material are defined in the End User Agreement. 


\section{CentAUR}

Central Archive at the University of Reading

Reading's research outputs online 


\title{
Unravelling the effects of cultural differences in the online appraisal of hospitality and tourism services
}

\begin{abstract}
International travelling has increased the likelihood of service interactions between customers and providers of different nationalities, frequently speaking various language, and repeatedly experiencing issues with intercultural communication. By examining more than 700,000 online reviews written by hotel guests of 101 different nationalities, using 84 different languages in their reviews, this study unravels cultural differences and examines through a direct measurement approach the simultaneous influence of national and linguistic differences between service customers and providers on online review valence. After controlling for reviewers' demographics, behavioral features, trip related factors and location of service provider, the study findings reveal that while the influence of national cultural distance on online ratings is country- and destination- dependent, the usage of a common language is positively associated with online review valence irrespective of the destination/country where the service provider is located. Theoretical and practical implications are discussed.
\end{abstract}

Keywords: Language difference, cultural distance, nationality, online reviews, eWOM, pilot study. 


\section{Introduction}

The global travel market has recorded a significant expansion over the last six decades, with international tourist arrivals that have grown steadily to reach 1.4 billion in 2018 (UNWTO, 2019). While the development of technologies in information and transportation has significantly affected the aforesaid growth, it has also made it simple and convenient for tourists and visitors to travel to a growing number of destinations (Mariani, Buhalis, Longhi \& Vitouladiti, 2014). Furthermore, the evolution of ICTs and the underlying digital technologies is increasingly enabling travelers to interact online with a wide array of individuals (Mariani, Baggio, Buhalis \& Longhi, 2014; Mariani, 2020) displaying different cultural traits and backgrounds through the production of electronic word-of-mouth (eWOM) about hospitality and tourism services in the form of online reviews (Baka, 2016). Moreover, the Internet has facilitated connections among service providers and consumers belonging to different language groups, thus stimulating a pronounced growth in inter- and cross-cultural communication (Holmqvist \& Grönroos, 2012). Among services industries, the hospitality and tourism industry has witnessed the most significant growth in intercultural communication: firms operating in this industry get in contact on a daily basis with customers from dissimilar cultural backgrounds (Mazanec et al., 2015).

Thus far, cross-cultural and inter-cultural interactions and their appraisal have been mostly analyzed by way of traditional surveys conducted on relatively small samples of services customers in offline settings (Mattila, 2000; Wang et al., 2015). Conversely, to date insufficient scholarly consideration has been given to the influence of cultural differences between service providers and customers on the online evaluation of hospitality services through online consumer reviews. Exceptions are represented by a handful of recent studies (Gao et al., 2018; Mariani and Predvoditeleva, 2019; Mariani, Di Fatta \& Di Felice, 2019; Mariani, Borghi \& Kazakov, 2019) that examined the extent to which specific cultural 
dissimilarities (either in terms of cultural values and nationality or, separately, language) can influence online review valence without a comprehensive measurement of the effects of multiple cultural differences. This research gap needs to be bridged as contemporary hospitality and tourism services are increasingly evaluated through Online Travel Agencies (OTAs) such as Expedia.com and Booking.com, and online travel review websites such as TripAdvisor, from consumers spread all over the world. Relatedly, online reviews (ORs) are becoming extremely relevant for firms' profitability and consumers' purchasing decisions globally (Filieri \& McLeay, 2014; Sparks \& Browning, 2011).

National and language differences augment the likelihood of misunderstandings, communication gaps and breakdowns (Holmqvist, 2011; Holmqvist \& Grönroos, 2012). However, scholars have not yet understood to what extent cultural differences between hospitality service customers and providers - both in terms of national cultural values and of language - can simultaneously affect ORs' valence. To this aim, and leveraging a combination of functionalist and anthropology theories of linguistics (Dik, 1980; Duranti, 2003; Martinet, 1969; Silverstein, 2004) and the concept of cultural distance between national cultures (Kogut \& Singh, 1988), the present study disentangles cultural differences between hospitality service customers and providers, measuring simultaneously national (country of origin) differences and language dissimilarities in multiple hospitality service contexts located in distinctively different tourism destinations and countries. To make the aforementioned contribution, this study adopts a "direct measurement approach" (Huang \& Crotts, 2019) to the analysis of cultural influences on hotel guests' behaviours, leveraging more than 700,000 service interactions involving guests of 101 different nationalities, using 84 different languages.

\section{Literature review and hypotheses development}

\subsection{Hospitality service interactions and customers' service appraisal}


Since the 1970s, services marketing scholars have acknowledged that consumers' participation in the service production is of paramount importance for service quality (Grönroos, 1978; Shostack, 1977). With the subsequent introduction and development of the co-creation paradigm (Vargo \& Lusch, 2004) services marketing research has accentuated to a greater extent the role of the consumer as a pivotal actor in co-creating value with the service provider. Thus, services have been conceived as interactions and/or encounters between providers (e.g., contact personnel) and customers (Shostack, 1985; Zeithaml et al., 1996). Effective service interactions have been found to engender positive experience (Arnould \& Price, 1993), enhanced customer satisfaction and pleasure (Russell et al., 1989), and ultimately also repurchase behaviours and loyalty (Mattila, 2001) that can affect firm performance (Sainaghi et al., 2013).

There are three relevant sets of factors and determinants related to service interactions in general and hospitality and tourism service encounters in particular: they are related to service customers, service providers, and the interaction between service customers and providers (Mariani, Borghi \& Kazakov, 2019). The role played by national differences has received a fair attention in consumer behaviour studies in hospitality and tourism research since the nineties (e.g., Crotts \& Erdmann, 2000; Mattila, 2000, 2001; Mazanec et al., 2015; Reisinger \& Crotts, 2010; Sparks \& Callan, 1992; Sultan \& Simpson, 2000). Apparently, over the last five years it has recorded a slight rise of interest (Gao et al., 2018; Huang \& Crotts, 2019). Instead, language differences have been largely neglected to date, with rare exceptions (e.g., Liu et al., 2017; Mariani, Borghi \& Kazakov, 2019; Schuckert et al., 2015).

\subsection{Country of origin differences, cultural distance and customers' appraisal of hospitality and tourism service interactions}


From the second half of the 1990s, a number of inter-, multi- and cross-cultural studies have been taken to completion with the purpose of comparing expectations, attitudes, evaluations and behaviours of hotel guests from Eastern countries vs. hotel guests from Western countries (Crotts \& Erdmann, 2000; Mattila, 2001; Mok \& Armstrong, 1998; Reisinger \& Turner, 1999). Most of the aforementioned ground-breaking studies were conducted in the form of field studies or experiments involving a few hundreds of tourists and hotel customers of two or three different nationalities. Their findings were interpreted by leveraging theoretical frameworks developed in the Eighties (Hall, 1984; Hofstede, 1980). Presumably, the prevalent theoretical paradigm deployed is the one developed by the Dutch scholar Geert Hofstede (Hofstede, 1980) who defined culture as "collective programming of the mind that distinguishes the members of one group or category of people from others" (Hofstede, 2011, p.3).

The framework's underlying assumption is that culture pertains to societal groups that can vary in size and in several cases, they might be large enough to overlap with an entire nation or a country. In line with earlier quantitative approaches, Hofstede (1980) observed that people belonging to different national cultures display different cultural traits and therefore cultural features that can be captured by deploying different "dimensions" that are societaldimensions and relate to vital issues that each society has to face to ensure its long-term survival. After a monumental field study conducted on a large multinational's employees, the Dutch scholar identified originally four different dimensions of culture: power distance (PD), individualism (IDV), masculinity (MAS), and uncertainty avoidance (UA), and later added also long-term orientation and indulgence (Hofstede, 2011). Table 1 includes the definition of each dimension.

\section{[Insert Tale 1 here]}


Even though the framework has received a few criticisms over time (McSweeney, 2002), still a vast majority of cross- and multi-cultural studies in the social sciences and tourism are deploying it. For instance, in her interpretation of the study reviewed above, Mattila (1999) explains that the main reason of statistically significant differences in the evaluation of hospitality services (services rated higher by Western travellers) across cultures can be explained based on the different levels of "power distance", with Asian cultures displaying relatively higher level of power distance than Western cultures. In their turn, Reisinger and Turner (1999) emphasize that Japanese guests look for personal relationships in hospitality and tourism service encounters as the Japanese society is more collectivist than Western ones. Low levels of individualism are consistent with extended relationships, consensus, cooperation and submission to group decision. More recently, a new research stream has been initiated, proposing to deploy the cultural dimensions by means of a direct measurement approach (Huang \& Crotts, 2019), whereby the researcher operationalizes cultural differences relying on the Hofstede's cultural dimensions and measures the correlations of those dimensions with tourists' satisfaction. Studies adopting a direct measurement approach to culture, use ex ante the Hofstede's cultural dimensions as measurement variables of culture in the model specification, while most of the previous literature (adopting an indirect measurement approach) on cultural differences (e.g., Mattila, 1999, 2000) used the cultural dimensions as contextual conditions in the research design (mostly to compare Western vs. Eastern cultures) or ex post to interpret differences of evaluations of hospitality services across different cultural groups. In this latter case the Hofstede's cultural dimensions are not used as variables in a model specification, but are deployed mostly to contextualize and interpret the results stemming from the surveys.

In online settings, scholars have overlooked the role that cultural factors could play in the evaluation of hospitality services, apart from four recent studies (Gao et al., 2018; 
Mariani \& Predvoditeleva, 2019; Mariani, Di Fatta \& Di Felice, 2019; Stamolampros et al., 2019). In their study of airlines' services, Stamolampros et al. (2019) embed the Hofstede dimensions of culture into a measure of cultural distance - that was originally deployed by Kogut and Singh (1988) to study the role played by national cultural differences on online ratings. While using the mere individual Hofstede dimensions (e.g., power distance) allows to explain how nationality of the individual customer affects her online consumer behaviour, focusing on cultural distance allows capturing cross-national differences between service provider and customer. Accordingly, it seems appropriate to adopt cultural distance as an effective proxy to capture the effect of national cultural factors in service interactions as the latter ones are essentially relational. By construction the measure of cultural distance (Kogut \& Singh, 1988) can be operationalized in the context of service interactions as follows:

$$
\text { Cultural Distance }_{c p}=\frac{1}{4} \sum_{i=1}^{4} \frac{\left(D_{c i}-D_{p i}\right)^{2}}{V_{i}}
$$

The formula captures the cultural distance between the service customer $c$ and the service provider $p$, where $\mathrm{D}_{\mathrm{ci}}$ and $\mathrm{D}_{\mathrm{pi}}$ denote the $\mathrm{i}$-th Hofstede dimension for the country of origin of the customer $c$, and the service provider $p$, respectively, and $\mathrm{V}_{\mathrm{i}}$ indicates the variance of the same Hofstede dimension in the analysed sample.

A previous study conducted in airline service interactions (Stamolampros et al., 2019) found that cultural distance is always negatively associated with online review valence. However, that study did not disaggregate data and findings at the level of the destination country's culture. On the other hand, Huang and Crotts (2019) suggest that most of the studies examining the role of cultural distance overlook a critical issue, namely that "the calculation of cultural distance scores inevitably positions cultural distance as a relative concept, which largely depends on what the host destination is." (Huang and Crotts, 2019: p.235). We embrace this conceptual 
insight and argue that as hospitality services are solidly hooked into a specific destination, the cultural dimensions of the destination - and by extension those of the hospitality service providers operating within the destination - represent the benchmark against which guests assess the hospitality service. Now, if we focus on countries that display cultural values of Western national cultures vs. Eastern ones, service providers located in the former ones are likely to display higher levels of individualism and masculinity and lower levels of power distance compared to service providers located in the latter ones. For instance, comparing Australia and Hong-Kong, Huang and Crotts (2019) find that cultural distance is positively and significantly correlated to tourists' overall satisfaction with the destination for Hong-Kong (Eastern national culture), while it is negatively and significantly correlated to the overall satisfaction with the destination for Australia (Western national culture).

In line with the aforementioned empirical evidence and the underling conceptual insights proposed by Huang and Crotts (2019) that characterize cultural distance as a relative concept depending on the host destination, we move one step forward and hypothesize that contextual cultural differences at the destination level in the guise of a prevalently Western vs. Eastern benchmark culture, will have opposite effects on the online ratings given by hotel guests. This effect is magnified considering that the features of those hotel customer groups that are culturally more distant from the benchmark culture are those that by construction contribute the most to the effect of cultural distance on customers' evaluations of the service. More specifically, based on received literature in hospitality services marketing (e.g., Mattila, 1999; Reisinger and Turner, 1999; Shama, 1994; Schmitt and Pan, 1994), Eastern (e.g., Asian) customers tend to prefer a more institutionalized service delivery (in line with high levels of power distance underpinning their cultural norms) and personal relationships (in line with low levels of individualism), and are more focused on processes and personal relations (in line with high level of femininity) than Western customers who are more focused on the outcomes rather 
than the process component of the service delivery. While the globalization of hospitality services has largely homogenized and standardized the outcome component of services, it has affected the processes component to a much lesser extent (e.g., Li et al., 2016; Mattila, 1999; Reisinger and Turner, 1999). For instance, Japanese and Chinese guests still pay a lot of attention to the processes component of service delivery and on personal relationships, while this is not necessarily the case for Western guests (e.g., Li et al., 2016; Wagner, 2005). Consequently, it is likely that customers belonging to national cultures that are more sensitive to the process component of services (i.e., Eastern cultures) will evaluate negatively service providers whose benchmark culture is prevalently Western. This is consistent with the findings that service interactions designed to meet the standards of global travellers (revolving around Western cultural norms) are less satisfying for Eastern customer compared to their Western counterparts (Mattila, 2000).

On the other hand, it is likely that customers belonging to national cultures that are less sensitive to the process component of services will still evaluate positively (or neutrally) service providers whose benchmark culture is prevalently Eastern: in this case, superior levels of the processes component of service dictated by the institutionalization of service (Mattila, 1999) might be perceived as a value added by Western customers.

Overall, bringing together the arguments related to the relevance of the benchmark culture (e.g., Huang \& Crotts, 2019), and those related to the way Western/Eastern guests evaluate differently the processes component of hospitality services (e.g., Li et al., 2016; Mattila, 1999; Reisinger and Turner, 1999), we expect that if the benchmark culture is close to a prototypical Western culture (i.e., relatively high levels of individualism and masculinity and low levels of power distance), then the effect of cultural distance on online ratings would be overall negative because the (effect of the) cultural distance measure is mostly driven by Eastern customers that are sensitive to the process component of services. On the other hand, 
we expect that if the benchmark culture is close to a prototypical Eastern culture (i.e., relatively low levels of individualism and masculinity and high levels of power distance), then the effect of cultural distance on online ratings would be overall positive because the (effect of the) cultural distance measure is mostly driven by Western customers that would consider the process component as an addition that generates delight. Therefore, we hypothesize that:

Hypothesis 1: The cultural distance between a hospitality service customer and a provider's country of origin influences negatively (positively) the online review valence in countries/destinations characterized by a prevalently Western (Eastern) benchmark culture.

\subsection{Language discrepancies and customers' appraisal of hospitality service interactions}

Language is a complex concept. It consists of a communication system whose development and use are rooted in human culture. Based on the perspective of functional linguistics (Dik, 1980; Martinet, 1969), language is a tool for communication. However, it is also tightly entangled with cultural values as language is learned through social interaction and is often used to signal affiliation to a specific socio-cultural group according to linguistic anthropologists, sociolinguists, and ethnolinguists (Duranti, 2003; Silverstein, 2004). Based on linguistic anthropologists' stances, there is a "“conceptual link' between language and culture" (Silverstein, 2004) as culture is "performatively enacted, always indexically (re)created in context by the simple fact that to understand as well as to participate in an interaction one must presuppose such culture to be conceptualizations of the "what" and "who" in communicative context that are always already both shared and in the instance precipitated." (Silverstein, 2004: p. 645). In a nutshell, also the functional use of language during interactions presupposes the sharing of some basic cultural conceptualizations of the context (e.g., country) where communicative interactions happen. 
The role of language differences has become an increasingly relevant object of study in service marketing literature only during the last decade (Holmqvist, 2008, 2011; Holmqvist \& Grönroos 2012; Holmqvist et al., 2017). Previously, language has been examined in the wide marketing literature with reference to indirect communication inclusive of advertising and branding (Appiah, 2001; Grier \& Brumbaugh, 1999; Lass \& Hart, 2004). This seems rather paradoxical, as within service settings language is of the essence because the intrinsically intangible and interactive texture of services implies that language would increasingly affect how customers perceive and assess services interactions with enterprises (Holmqvist \& Grönroos, 2012).

In relation to the role of communication within the hospitality services, a number of scholars have contributed to the field since the 1990s looking at inter- and cross-cultural communication from a provider perspective ( $\mathrm{Yu} \&$ Siong Huat, 1995) and from a customer perspective (Sparks \& Callan, 1992). As far as the provider perspective is concerned, Yu and Siong Huat (1995) analyse 293 expatriate hotel professionals working in China and found that among the six most relevant issues, language barriers were extremely relevant. For Western expatriate hotel managers (European and North American) it was particularly difficult to communicate effectively with local staff and guests and language represented an almost unsurmountable obstacle. The authors therefore suggest that language training is of crucial importance as this can prepare expatriate hotel managers to deal with their overseas assignments and to offer a better service when interacting with guests. By adopting a communication perspective, Wang et al. (2015) examine explicitly service encounters in intercultural settings within a foreign context and find that Chinese customers react to communication accommodation strategies with heightened arousal and amplified felt pleasure that translates into higher levels of satisfaction. 
The role played by language before, during and after services interactions has been studied by several services marketing scholars led by Jonas Holmqvist (Holmqvist, 2008; Holmqvist et al., 2017; Holmqvist \& Grönroos, 2012). Holmqvist et al. (2017) underscore that relatively scarce attention has been devoted to understanding the role of language in services settings. One of the areas that seems worth exploring according to Holmqvist and Grönroos (2012) is the influence of language on word of mouth after service interactions (Balaji et al., 2017) as it is argued that language used during a service encounter might affect customers' repurchase and willingness to recommend the service provider.

Overall, this issue is even more relevant if we consider the expansion of eWOM and its increasing importance in hospitality. Within eWOM research (Hennig-Thurau et al. 2004), there is a dearth of studies trying to capture the influence of language on online customers' behaviour and evaluations of hospitality services. In their original analysis, Schuckert et al. (2015) investigate hotel customers employing English vs. those employing other languages in their ORs of Hong-Kong hotels. The examination finds that there are marked differences between guests using English vs. those using other languages and, more specifically, the latter ones prefer low-class hotels. Nonetheless, any generalization based on a single language (e.g., English) must be validated byleveraging data gathered from different language communities (Cenni \& Goethals, 2017;Holmqvist \& Grönroos, 2012). More recently, Liu et al. (2017) pay attention to more than 400 thousand ORs written in eight different languages by TripAdvisor users after their stay in Chinese hotels. They find that hotel guests assess hotel service attributes (such as cleanliness, location, etc.) differently across different language groups. The most recent study employing language in hospitality management draws a distinction between the usage and understanding of domestic versus non domestic language to address the impact of domestic language usage on online hotel review valence in two dissimilar destinations (Mariani, Borghi \& Kazakov, 2019). Based on a sample of almost 0.5 million ORs left by 
hotel guests on the Booking.com platform, the authors reveal that domestic language usage influences positively online ratings in two destinations.

Consistently with Mariani, Borghi \& Kazakov (2019), we propose to understand how online customers appraise hospitality services after cross-cultural service interactions, by distinguishing customers using vs. not using the language of service providers. This is in line with the theorizations of functional linguistics (Dik, 1980; Martinet, 1969) who support that language is a tool for communication. It is also compatible with the stances of linguistic anthropology (Silverstein, 2004) that suggest that there is a close nexus between language and culture as the very same linguistic interaction implies at least a minimal form of sharing of basic cultural references. It is not a coincidence that cultural products like songs and movies are often used to learn a foreign language because they help the learner of the language to connect with the culture where the language to be learned has been developed. Moreover, and consistently, literature in business has underlined that "language is a subset of culture and, especially in the business context, the one is inextricably linked with the other" (Block, 1996). Based on received theory in functional linguistics (Dik, 1980; Martinet, 1969), linguistic anthropology (Duranti, 2003; Silverstein, 2004) and the studies on language conducted in business (Block, 1996), marketing (Holmqvist et al., 2017) and hospitality marketing (Mariani, Borghi \& Kazakov, 2019), we conjecture that the use of the same language of the service provider can help minimizing instances of communication breakdowns and misunderstandings between service providers and customers, with a positive effect on eWOM. Accordingly, we hypothesize that:

Hypothesis 2: The use of the language of the hospitality service provider after the service interaction influences positively the online review valence, regardless of the characteristics of the country/destination. 
The reason why we test a language related hypothesis - similar but not identical to the one tested in Mariani, Borghi \& Kazakov (2019) - in a new setting and on a larger sample is first to guarantee external validation (Balaji et al., 2017; Lynch et al., 2015) of previous findings and secondly to build a joined up body of knowledge on the language effect, as in this study we look at the influence on online ratings of both language (Hypothesis 2) and cultural distance (Hypothesis 1) conjointly. This analysis is also among the few studies looking at actual online evaluations and behaviors unlike previous studies that focused on intentions (Balaji et al., 2017; Zhang et al., 2017). Therefore, in our research design, the two hypotheses are tested conjointly to understand what type of cultural difference (national vs. linguistic) plays the most relevant and paramount role in influencing online ratings.

\section{Empirical contexts and methods}

\subsection{Empirical contexts: multiple destinations in distinctively different countries}

To ensure a fair level of generalizability of our findings, our study is conducted in three dissimilar destinations located in three dissimilar countries characterized by distinctly different cultural milieus: namely London in the United Kingdom, Rome in Italy and Moscow in Russia. These three countries lead international tourism flows being among the top ten countries for international tourism (UNWTO, 2019). The three focal cities chosen are the city destinations attracting the higher number of tourists nationwide: London, Rome and Moscow recorded respectively 75.1, 26.9 and 17.6 million bed nights in 2016 (ECM, 2017). Despite their success in attracting tourism flows, these destinations are significantly different in terms of demand and supply, as well as benchmark culture, with London and Rome sharing similarities in terms of benchmark culture (Western) vis-à-vis Moscow (Eastern). 
First, as far as consumer demand is concerned, London and Rome are mostly leisure destinations (i.e., the share of leisure tourists is higher than the share of business tourists), whereas Moscow hosts an even share of business and leisure travellers. Secondly, Rome and London display a larger share of international guests than Moscow: out of 26.9 million and 75.1 million total bed nights recorded in 2016 in Rome and London respectively, 19.4 million (72.1\%) and 58.3 million (77.6\%) respectively relate to international tourists (ECM, 2017); instead, for the Russian capital only 5.5 out of 17.6 million overnight stays (31.3\%) concerned foreign travellers. The Booking.com data mirrors the features of the aforementioned flows (see Table 2). Figures 1.a, 1.b and 1.c illustrate the top five reviewer's countries of origin for the destinations analysed: Moscow displays the highest share of domestic tourists, whereas London and Rome are characterized by a larger and more heterogeneous group of international tourists.

\section{[Insert Table 2 here]}

\section{[Insert Figures 1.a, 1.b, 1.c here]}

Third, as far as language groups are concerned, we provide an illustration of the top five languages used in ORs endowed with text in Figure 2.a, 2.b and 2.c. In Moscow and London, the predominant language is the domestic one. In Rome, the most used language is English, and the overall distribution is smoother, with the domestic language in the second place while many international tourists visiting the British capital speak the domestic language (English). Interestingly, in Moscow, Russian is a dominant language not only due to a large proportion of domestic tourists but also in relation to visitors from former neighbour Soviet Union countries.

In addition to differences demand-wise, the three destinations also differ in terms of supply. First, the three different hospitality settings have followed a different historical development path (Craig 2016). Secondly, the distribution of hotels by category is different 
across destinations, with London having all the categories equally represented (Knight Frank, 2017). Third, and more importantly, service providers operate in three distinctively different cultural milieus and benchmark cultures: the UK and Italy represent Western national cultures, whereas Russia is much closer to Eastern national cultures. As clear from Figure 3, in three of the four cultural dimensions, namely PD, IDV and MAS, Russian cultural dimension indices are sharply different - in absolute value - compared to the Italian and the British ones. While Russia, as a national culture, scores high in power distance, collectivism, and femininity, Italy and the UK represent cultures with similarly lower levels of power distance, and higher levels of individualism and masculinity.

\section{[Insert Figures 2.a, 2.b, 2.c here] [Insert Figure 3 here]}

The aforementioned data and figures clearly illustrate that the destinations under analysis are remarkably different in respect of both demand and especially supply. Accordingly, we selected them as they exhibit a satisfactory degree of diversity and variance which complies with the idea of selecting "polar cases" (Eisenhardt, 1989) when conducting a pilot study to gain a better understanding of a phenomenon. More specifically, London and Rome represent Western benchmark cultures when thinking in terms of cultural distance, while Moscow represent an Eastern benchmark culture. Table 3 clarifies even further the differences in terms of national benchmarking cultures: it displays the scores for the selected destinations (i.e., related national cultures) in each of the four Hofstede's dimensions. If we make pairwise comparisons, the pairs Italy-Russia and UK-Russia are very different in terms of Hofstede dimensions. Indeed, Italy and the UK score high in the individualism dimension (76 and 89 respectively) while Russia scores significantly lower (39). Italy and the UK also display high masculinity scores (70 and 66 respectively) while Russia scores significantly lower (36). As far as the power distance dimension is concerned, Italy and the UK scores low (50 and 35 
respectively) compared to Russia (93). Accordingly, both Italy and the UK display a benchmark culture significantly different compared to Russia; a the same time, Italy and the UK display a similar benchmark culture.

\section{[Insert Table 3 here]}

That said, we should emphasize that the units of analysis of this study are service interactions happening in the aforementioned countries/destinations: more specifically we studied 710,804 hotel service interactions for which we collected ORs as explained in the data section. The study innovatively takes into account a high number of language groups thus overcoming a major limitation in extant literature that has examined mainly English language in services and hospitality services as outlined by Holmqvist and Gronroos (2012).

\subsection{Data}

\subsubsection{Data retrieval}

The research team retrieved data from Booking.com - one of the most successful and popular e-commerce platforms - which embeds the largest share of certified ORs globally (Revinate, 2017). Furthermore, Booking.com is indicated in conjunction with Expedia as a suitable source to ensure external validity in hospitality-related eWOM studies that so far have relied mainly on TripAdvisor (e.g., Filieri \& McLeay, 2014). The researchers used the Python programming language to develop a crawler to retrieve ORs of the hotels located in the three selected destinations in the time window January 2015 to January 2017.

Overall, data covers the entire population of hotel businesses that were featured on Booking.com in Rome, Moscow and London, consisting of 2,268 hotels and 1,212,281 ORs with text. Consistently with previous research, we retained only those reviews written by 
international tourists to control for home country biases (Gao et al., 2018). This implies that 253,064 reviews for Rome, 38,178 reviews for Moscow and 419,562 reviews for London were retained as those reviews were written by international tourists. Accordingly, the final sample consists of the sum of the reviews retained and sums up to 710,804 ORs across the three destinations. Reviewers are originally from 100, 91 and 100 countries in Rome, Moscow, and London respectively (excluding the home country). Moreover, in terms of language, reviews were written in 79 different languages for Rome based hotels, 65 different languages for Moscow based hotels, and 77 different languages for London based hotels. An overall snapshot of the diversity of the ORs considered is offered in Table 4.

\section{[Insert Table 4 here]}

\subsubsection{Variables}

The dependent variable of the study consists of the OR rating that varies in a range of 2.5 to 10.0 on the Booking.com platform (Mariani \& Borghi, 2018). The independent variables encompass the cultural distance between the hospitality service provider and the guest's country of origin and the language (whether the same of the hotel providers or not) deployed to write the review. The measure of cultural distance is borrowed from Kogut and Singh (1988) that deployed it to study how and if cross-national differences affect firm's entry modes in foreign countries/markets (see equation 1). It considers only the original four Hofstede's dimensions due to several missing data related to the newest two dimensions (long term orientation and indulgence) for the countries in our sample. Consistently with Gao et al. (2017), we included the average observed rating variable on the basis of the full rating history of each hospitality enterprise that we retrieved from Booking: this number varies as the reviewer accesses the Booking.com platform and posts her reviews at different moments in time. In 
addition, we included other reviewer-level variables entailing reviewer's gender, the degree of online identity disclosure, and trip-related metrics including the length of stay, travel companions and the purpose of trip. We also controlled for firm-level data such as hotel class (operationalized as number of stars) and whether the hospitality enterprise was part of a chain or not. The variables' description is illustrated in Table 5. The variables' descriptive statistics are presented in Tables 6.a, 6.b and 6.c.

\section{[Insert Table 5 here]}

\section{[Insert Table 6.a, 6.b, 6.c here]}

\subsubsection{Data analysis}

The two focal hypotheses were tested adopting a Tobit regression model, particularly suitable when the dependent variable is continuous and censored like in the case of Booking.com (see Mariani \& Borghi, 2018). The model specification is as follows:

$$
\begin{aligned}
\text { Rating }_{r h}= & \beta_{0}+\beta_{1}(\text { Cultural_Distance })_{r h}+\beta_{2}(\text { Language })_{r h}+\beta_{3}(\text { Obs_Avg_Rating })_{r h}+ \\
& \beta_{4}(\text { No_Identity_Disc })_{r h}+\beta_{5}(\text { Female })_{r h}+\beta_{6}(\text { LoS })_{r h}+\beta_{7}(\text { Solo })_{r h}+ \\
& \beta_{8}(\text { Leisure })_{r h}+\beta_{9}(\text { Hotel_Star_Rating })_{r h}+\beta_{10}(\text { Chain })_{r h}+\varepsilon_{r h}
\end{aligned}
$$

As clear from the equation, we regressed the dependent variable (i.e., the OR rating) of reviewer "r" of hotel "h" against the focal explanatory variables.

\section{Findings and discussion}

Empirical results show that cultural distance between a hotel guest and a hotel enterprise's nationality has a negative and significant influence $(\mathrm{p}<0.001)$ on the OR valence for the Italian and British samples, as hotel service providers are located in countries characterized by a prevalently Western benchmark culture (characterized by high levels of individualism and 
masculinity and low levels of power distance). On the other hand, the cultural distance between a hotel guest and a hotel's country of origin has a positive and significant influence $(p<0.001)$ on the OR valence for the Russian sample, as hotel service providers are located in a country characterized by a prevalently Eastern benchmark culture (characterized by relatively lower levels of individualism and masculinity and higher levels of power distance compared to prevalently Western cultures)(see Table 7). Accordingly, our first hypothesis is supported. This result corroborates the idea that national cultural distance plays a significant role in hospitality services interactions and that the effect of cultural distance between a hotel guest and a hospitality provider's country of origin will affect differently OR ratings, based on the benchmark culture of the country/destination where the hotel is located. Secondly, the coefficient related to the hotel guests' usage of the providers' language suggests that domestic language has a positive and significant influence $(\mathrm{p}<0.001$ for London and Moscow and $\mathrm{p}<0.05$ for Rome) on OR valence across the three destinations under analysis, irrespective of the country where the hospitality enterprises are located, the degree of internationalization of the destination and the type of tourist flows that it mainly attracts (mainly business vs. leisure tourism flows). Accordingly, our second hypothesis is supported. This result suggests that the deployment of the same language represents a solid departing point for effective inter-, multiand cross-cultural communication between hospitality service customers and providers, allowing to minimize the likelihood of communication gaps, and misunderstandings (Holmqvist et al., 2017; Manzur \& Jogaratnam 2007). This finding offers a strong validation of previous findings in the hospitality management literature (Mariani, Borghi \& Kazakov, 2019), further substantiating that language can influence service customers' satisfaction regardless of the destination and country where the hospitality enterprises are located.

Thirdly, we can appreciate that the magnitude of the language coefficient is two to seven times higher than the magnitude of the cultural distance coefficient. Given that the 
difference between coefficients is statistically significant within all the three subsamples, based on both the Wald test and the incremental F test, we can conclude that ceteris paribus and within a specific destination, the influence of language on online customer satisfaction appears to be more relevant than the influence of cultural distance. The result by no means implies a rigid causal relationship and seems to suggest that among the cultural factors that have been analysed so far in services marketing and management literature, language seems to have a more predictive power than the mere Hofstede cultural dimensions or their compounded effects captured by the cultural distance variable.

\section{[Insert Table 7 here]}

Looking at the reviewer-level variables, the absence of disclosure of identity seems to be negatively associated $(p<0.001)$ with the overall review valence. This result is not consistent with a previous study employing this variable (Gao et al., 2018). The negative effect that this study detected can be interpreted in light of the reflection that reviewers that do not disclose their identity online might articulate their opinions more freely than other reviewers and be more objective and conservative in their online ratings. Consistently with previous studies (Gao et al., 2018), women rate hotels significantly higher $(\mathrm{p}<0.001)$ than their male counterparts. Reviewers staying for more time in a hotel tend to give slightly yet significantly higher ratings ( $\mathrm{p}<0.001$ for London and Rome, $\mathrm{p}<0.01$ for Moscow) than those whose length of stay is shorter. Reviewers travelling for leisure give high online evaluations (coefficients are positive, $\mathrm{p}<0.001)$. Consistently with studies highlighting that OR ratings are influenced by social dynamics (e.g., Gao et al., 2017), the observed average ratings influence positively and significantly the dependent variable.

\subsection{Robustness Checks and supplementary analyses}


We carried out robustness checks to test the validity of our assumptions in different subsamples for each destination. Accordingly, we created different subsamples based on the year when the ORs were written to test our econometric model. Therefore, we split the overall dataset of each of the three destinations into two different subsamples, one containing ORs written in 2015 and the other ORs written in $2016^{1}$. The results of the analyses of these robustness checks (shown in Tables 8 and 9) are consistent with the results of the overall analysis.

\section{[Insert Tables 8 and 9 here]}

In line with the recommendations of Agresti (2007), we performed an additional robustness check for missing values, and estimated a further econometric model removing observations presenting missing values related to the inferred gender. As it is visible in Table 10, the effect and significance levels of the focal variables and all other covariates does not change using this particular sample, ensuring the validity of our results.

\section{[Insert Table 10 here]}

Overall, in addition to our robustness checks, we carried out a more fine-grained supplemental analysis by computing pair-wise overall sum of differences in absolute values of the cultural dimensions across the three destinations examined. Leveraging Table 11 that carries out a pair wise destination differences assessment, in three of the four cultural dimensions (namely PD, IDV and MAS), Russian cultural dimension indices are sharply different - in absolute value compared to the Italian (with the overall sum of differences in absolute values being 134) and

\footnotetext{
${ }^{1}$ The sum of the observations of the two samples does not yield the overall number of observations of the general model since for the general model we also included observations for January 2017.
} 
the British (with the overall sum of differences in absolute values being 198) ones. While Russia, as a national culture, scores high in terms of power distance, and is highly collectivistic, and feminine, Italy and the UK represent cultures with similarly lower levels of power distance, highly individualistic and masculine. On the other hand, Italian and British cultural dimensions indices are relatively similar (with the overall sum of differences in absolute values being 72). Overall, this means that while the UK and Italy represent Western national cultures, Russia represent an Eastern national culture (more similar to Asian national cultures).

Consequently, taking Russia on the one hand and Italy and the UK on the other hand as the benchmark culture to calculate the cultural distance scores, similar cultural distance values in the Russian vs. Italian or Russian vs. British sample would mean opposite positions of the respondent's home culture. More specifically, if we focus on power distance, Italy and the UK score much lower than Russia. This means that Eastern tourists (for instance Asian tourists) visiting Rome or London, due to their attention to the processes component of services (Mattila, 1999), might be not satisfied with the lack of attention to services processes, and this might translate into lower online ratings. On the other hand, Western tourists (for instance US tourists) visiting Moscow, might find in the service delivery an enhanced process component that might generated delight and translate into higher online ratings.

\section{[Insert Table 11 here]}

\section{Implications}

Leveraging on a dataset consisting of more than 700,000 ORs covering hospitality service interactions in the most visited destination cities in Italy, Russia and the United Kingdom, this paper has unravelled and unpacked cultural differences and examined the conjoint influence of cultural distance and language dissimilarity between hospitality service customers and providers on customers' OR valence. 
Three key research findings emerge from our pilot study. First, the cultural distance between a hotel guest and a hotel's country of origin influences in a differentiated way online customer review valence across countries. More specifically, it affects negatively OR valence in countries where service providers are characterized by a prevalently Western benchmark culture. The opposite holds in countries with service providers displaying a prevalently Eastern benchmark culture. This result extends findings stemming from research conducted in tourists' satisfaction with a destination (Huang and Crotts, 2019) and points to the fact that the cultural distance affects differently OR valence based on the nature and characteristics of hospitality services supply in the focal destination. Accordingly, the study's findings reinforce the conceptual insight that cultural distance is "a relative concept, which largely depends on what the host destination is." (Huang and Crotts, 2019: 235). This implies that caution should be in place when analysing the influence of cultural distance on OR valence of hospitality services across different contexts and destinations. Overall, the finding complements recent studies capturing the influence of cultural value orientations in consumers' use of eWOM (Nath et al., 2018).

Second, hotel guests' usage and understanding of hotel services providers' language influences positively OR ratings regardless of the destination and country examined in line with recent research conducted in the hospitality sector (Mariani, Borghi \& Kazakov, 2019) thus corroborating extant literature in the wider services marketing field suggesting that language exerts a critical role in customers' evaluations after services interactions (Holmqvist et al., 2017) because speaking a destination's language implies a better connection with the local culture in line with linguistic anthropology studies (Duranti, 2003; Silverstein, 2004). Third, the magnitude of the language coefficients is two to seven times higher than the magnitude of the cultural distance coefficients, depending on the national sample considered. This statistically significant difference indicates that language seems to have a more predictive 
power than the mere Hofstede's cultural dimensions and/or their compounded effects captured by the cultural distance variable.

\subsection{Theoretical contributions}

This study makes several theoretical contributions. First, this is one of the first attempts to unravel and unpack cultural differences in the online evaluation of services. More specifically, our study is distinctive because it analyses conjointly how and to what extent cultural distance and language differences between hotel service customers and hotel service providers affect online customer ratings and behaviours. Accordingly, this study proposes a comprehensive and holistic "third way" to assess the influence of cultural factors on online customer ratings if compared with previous studies that have focused only either on individual customers' cultural traits (Gao et al., 2018; Mariani \& Predvoditeleva, 2019; Mariani, Di Fatta and Di Felice, 2019) or on language (Liu et al., 2017; Schuckert et al., 2015). Accordingly, we blend theorizations of functional linguistics (Dik, 1980; Martinet, 1969) and linguistic anthropology (Silverstein, 2004) that look at language as a tool of communication and a component of culture. Indeed, there is a close nexus between language and culture because culture is "performatively enacted, always indexically (re)created in context by the simple fact that to understand as well as to participate in an interaction one must presuppose such culture to be conceptualizations of the "what" and "who" in communicative context that are always already both shared and in the instance precipitated." (Silverstein, 2004: p. 645). Due to this language-culture nexus, we contribute to extant knowledge within the eWOM research stream, by assessing simultaneously different nuances of culture - namely cultural values underlying nationalities subsumed by the

cultural distance on the one hand and the language spoken on the other hand - on online customer ratings. 
Secondly, we discover differences in the way cultural distance influences online ratings across distinctively different destinations and countries, and offer explanations based on destinations' and countries' benchmark culture. Accordingly, we extend previous conceptualizations of cultural distance (Huang and Crotts, 2019) and move one step forward by hypothesizing and testing that contextual cultural differences at the destination level in the guise of a prevalently Western vs. Eastern benchmark culture, have opposite effects on the online ratings given by hotel guests. This effect is justified also looking at the hotel customer groups that are culturally more distant from the benchmark culture are those groups by construction contribute the most to the effect of cultural distance on customers' evaluations of the hospitality service. Accordingly, we offer a complementary conceptual insight to that offered by Huang and Crotts (2019) and enrich the direct measurement approach with insights offering a more fine-grained appreciation of the relative vs. absolute nature of the concept of cultural distance in light of differences across a continuum along which Western and Eastern culture fall.

Third, this study adds to international marketing research that has employed the cultural distance variable (Kogut \& Singh, 1988) as a proxy of the cultural differences between service providers and consumers by validating previous findings and extending them into a different context: hospitality and tourism services interactions. Simultaneously, we emphasize that the relational nature of the Cultural Distance metric is particularly suitable for capturing crossnational differences between service providers and customers. Fourth, in its consideration of language, this paper simultaneously enhances our comprehension of the role that language plays in business (Block, 1996), marketing (Holmqvist et al., 2017), and more specifically services marketing settings (Holmqvist \& Grönroos, 2012) and informs our theoretical appreciation of the effect of language in online settings in hospitality services, hence moving beyond the more traditional segmentation by language (e.g., Schuckert et al., 2015) and taking 
into account both functionalist (Martinet, 1969) and anthropology (Silverstein, 2004) views of language. Relatedly, it corroborates and validates the results of a recent study revealing that the language used (domestic language) can make a difference in the online appraisal of hospitality services after service interactions (Mariani, Borghi \& Kazakov, 2019). Last, this paper adds to the wider services marketing literature by identifying and evaluating the influence of the cultural discrepancies between hospitality and tourism services customers and providers and individual reviewers' features - such as demographics and behavioural features - as well as trip-related factors on OR valence, by leveraging a large sample of more than 700,000 service interactions covering multiple distinctively different destinations/countries that display a significant degree of variance in terms of service cultures on the service provider side, and different mixes of leisure/business and domestic/international tourists on the service customer side. Leveraging on this large and longitudinal data from the aforementioned distinctively different destinations ensures robustness of our findings and allows us to observe the same phenomenon (hospitality interactions) happening in contexts that display different (Western vs. Eastern) benchmark cultures.

\subsection{Practical implications}

This paper generates several practical implications that might be of relevance for a number of stakeholders including hospitality professionals and practitioners, managers of OTAs and hospitality services customers. First, hospitality professionals could progressively match analytics stemming from relevant volumes of ORs with hotel service evaluations generated through more traditional surveys. This would allow hotel managers to gain insights from multiple sources and triangulate digital streams of big data (Pigni et al., 2016) with small data generated at discrete moments in time through traditional surveys (Li et al., 2018). Second, managers could deploy the research findings to better understand guests' perceived quality 
based on their used language in conjunction with their country of origin. More specifically, they could ask their guests what language they prefer to use during their stay upon arrival and record this preference into an internal database. This might provide hotel managers with a knowledge and cultural base to avoid communication gaps and misunderstandings during service interactions and encounters, conducive to the generation of positive eWOM after the hospitality service interaction (Holmqvist \& Grönroos 2012). Third and related to the previous point, hotel professionals might accommodate their communication (including spoken, written and body language) during and after the hospitality service interaction (Wang et al., 2015) on the basis of the language originally used by their customers: this issue might not be an easy one as when online bookings and reservations are made, typically managers can trace the country of origin or residence of their future customer, but not automatically her preferred spoken language, which might in turn differ from their preferred written language (that could be used for a specific inquiry).

As far as developers and managers of OTAs are concerned, they should be aware that operating in multilingual environments is the rule nowadays, and that online platforms should be endowed with a multifaceted set of features allowing for interaction with multiple language communities (Cenni \& Goethals, 2017). First, from an OR platform usability point of view, our findings are relevant as they suggest that language should be amid the foremost features and criteria provided to Internet users to filter, browse and order online reviews. Secondly, review platforms could offer automatic translation of the reviews' text (Cenni \& Goethals 2017), to allow foreign reviewers to interact with the domestic ones thus enhancing their knowledge base about a service before consumption and encouraging the value co-creation process. The market is going multilingual and with the progress in translations technologies, it is certainly warranted that OR platforms should keep on investing in developing multilingual mechanisms and features (Lenihan, 2011). 


\section{Conclusions, limitations and future research}

This study has contributed to the expanding research line addressing the influence of cultural differences between services providers and customers on online customer reviews. More specifically, this paper has enriched the emerging eWOM literature related to the influence of cultural distance (Stamolampros et al., 2019) and language (Schuckert et al., 2015) on ORs, thus enriching the growing body of eWOM research within the hospitality and tourism field. By combining functionalist and anthropology theories of linguistics (Dik, 1980; Duranti, 2003; Martinet, 1969; Silverstein, 2004) and the concept of cultural distance between national cultures (Kogut \& Singh, 1988), this study proposes a comprehensive "third way" to assess thoroughly and holistically the influence of cultural factors on online review valence if compared with previous studies that have focused only either on individual customers' cultural traits (Gao et al., 2018; Mariani, Di Fatta \& Di Felice, 2019; Mariani and Predvoditeleva, 2019) or on language (Mariani, Borghi \& Kazakov, 2019; Schuckert et al., 2015). Secondly, we use large datasets and statistical analyses to gain an in depth understanding of the influence of cultural factors on OR ratings. We build and extend previous conceptualizations of cultural distance based on a direct measurement approach (Huang and Crotts, 2019) and move one step forward by hypothesizing and testing that contextual cultural differences at the destination level in the guise of a prevalently Western vs. Eastern benchmark culture, have opposite effects on the online ratings given by hotel guests. Based on a large sample of more than 700,000 hospitality service interactions and their respective ORs, we found that national cultural distance affects negatively OR valence in countries where service providers are characterized by a prevalently Western benchmark culture (characterized by relatively low levels of power distance, and relatively high levels of individualism and masculinity). The opposite holds in countries characterized by a prevalently Eastern benchmark culture (characterized by relatively 
high levels of power distance, and relatively low levels of individualism and masculinity). Thirdly, we have corroborated the finding that hotel guests' usage and understanding of hotel services providers' language is positively associated with OR ratings regardless of the destination and country examined in line with recent research conducted in the hospitality sector (Mariani, Borghi \& Kazakov, 2019). This finding is coherent with services marketing literature stressing that language plays a paramount role at each stage of services interactions (Holmqvist et al., 2017) acting as a critical connection with the local culture in line with linguistic anthropology studies (Duranti, 2003; Silverstein, 2004), and ultimately leading to the generation of positive eWOM after interactions. Third, the magnitude of the language coefficients is higher than the magnitude of the cultural distance coefficients in each national sample. This statistically significant difference might indicate that language has a more predictive power than the mere Hofstede cultural dimensions or their compounded effects captured by the cultural distance variable. This finding seems to reveal that studies that have tried to assess the impact of individual cultural traits on online customer satisfaction (Gao et al., 2018; Stamolampros et al., 2019) might benefit from embedding language as a further crucial explanatory variable in future model specifications. Taken together, our results contribute to disentangle and unpack individual cultural differences within the wider category of "cultural differences". Moreover, the research findings can be generalized as we leverage on big data (Liet al., 2018Mariani et al., 2018; Mariani, 2019) extracted from ORs.

The study has some limitations. First, this is a pilot study that could be extended to other destinations and countries: while we were able to cover a number of distinctively different destinations, future work might be carried out to generalize our findings by empirically testing our model on additional destinations including additional destinations displaying a Western benchmark culture (e.g., destinations in the US) or an Eastern benchmark culture (e.g., destination in Asia and more specifically in countries like China and Japan). Relatedly, a 
further external validation of the findings might be sought by comparing different platforms including the competing OTA Expedia and the online travel website TripAdvisor. In parallel, while considering large samples, it should be noted that large dataset might potentially lead to Type 1 errors as recognized in the statistics literature (Huang et al., 2011; Van der Laan et al., 2010). Second, further variables such as the submission device used to write the review (Mariani, Borghi and Gretzel., 2019) and variables such as location, facilities, proficiency of employees, company management could be embedded into the model specification as control variables. Finally, it could be valuable to juxtapose OR valence to text analytics to understand if text readability and polarity vary across cultural and language groups. 


\section{References}

Agresti, A. (2007). An Introduction to Categorical Data Analysis . Hoboken: John Willey and Sons. Inc. Second Edition

Andraz, J.M., \& Rodrigues, P.M.M. (2016). Monitoring tourism flows and destination management: Empirical evidence for Portugal. Tourism Management, 56, 1-7.

Appiah, O. (2001). Ethnic identification on adolescents' evaluations of advertisements. Journal of Advertising Research, 41(5), 7-22.

Arnould, E.J., \& Price, L.L. (1993). River magic: Extraordinary experience and the extended service encounter. Journal of Consumer Research, 20(1), 24-45.

Baka, V. (2016). The becoming of user-generated reviews: Looking at the past to understand the future of managing reputation in the travel sector. Tourism Management, 53, 148-162.

Balaji, M.S., Roy, S., \& Lassar, W. (2017). Language divergence in service encounters: Revisiting its influence on word-of-mouth. Journal of Business Research, 72, 210-213.

Block, B. (1996). The Language-culture Connection in International Business, Foreign Language Annals, 29(1), 27-36.

Cenni, I., \& Goethals, P. (2017). Negative hotel reviews on TripAdvisor: A cross-linguistic analysis. Discourse, Context \& Media, 16, 22-30.

Craig, Z. (2016). London's Most Historic Hotels. Retrieved October 19, 2019, from https://londonist.com/london/history/historic-hotels

Crotts, J.C. \& Erdmann, R. (2000). Does national culture influence consumers' evaluation of travel services? A test of Hofstede's model of cross-cultural differences. Managing Service Quality: An International Journal, 10(6), 410-419.

Dik, S.C. (1980). Studies in Functional Grammar. London: Academic

Duranti, A. (2003). Language as Culture in U.S. Anthropology: Three Paradigms, Current Anthropology, 44(3), 323-348.

Eisenhardt, K.M. (1989). Building theories from case study research. Academy of management review, 14(4), 532-550.

European Cities Marketing, ECM. (2017). ECM benhmarking report 16/17. 13th Edition. Dijon: ECM.

Filieri, R., \& McLeay, F. (2014). E-WOM and accommodation: An analysis of the factors that influence travelers' adoption of information from online reviews. Journal of Travel Research, 53(1), 44-57.

Gao, B., Hu, N., \& Bose, I. (2017). Follow the herd or be myself? An analysis of consistency in behavior of reviewers and helpfulness of their reviews. Decision Support Systems, 95, 1-11.

Gao, B., Li, X., Liu, S., \& Fang, D. (2018). How power distance affects online hotel ratings: the positive moderating roles of hotel chain and reviewers' travel experience. Tourism Management, 65, 176-186.

Grier, S. \& Brumbaugh, A. (1999). Noticing cultural differences: ad meanings created by target and non-target markets. Journal of Advertising, 28(1), 79-93.

Grönroos, C. (1978). A service-orientated approach to marketing of services. European Journal of Marketing, 12(8), 588-601.

Hall, E.T. (1984). The Dance of Life.. NY: Doubleday.

Hennig-Thurau, T., Gwinner, K.P., Walsh, G., \& Gremler, D.D. (2004). Electronic word-of-mouth via consumer-opinion platforms: what motivates consumers to articulate themselves on the internet? Journal of Interactive Marketing, 18(1), 38-52.

Hofstede, G. (1980). Culture's Consequences: International Differences in Work-Related Values. CA: Sage Publications.

Hofstede, G. (2001). Culture's consequences: comparing values, behaviors, institutions, and organizations across nations. 2nd edition. CA: Sage Publications.

Hofstede, G. (2011). "Dimensionalizing Cultures: The Hofstede Model in Context", Online Readings in Psychology and Culture, 2(1).

Holmqvist, J. (2008), "When language influences service encounters", in Goudarzi, K., Llosa, S. 
\& Orsingher, C. (Eds), Proceedings from the 10th International Research Seminar in Service Management, 146-63.

Holmqvist, J. (2011). Consumer language preferences in service encounters: a cross-cultural perspective, Managing Service Quality: An International Journal, 21(2), 178-191.

Holmqvist, J., \& Grönroos, C. (2012). How does language matter for services? Challenges and propositions for service research. Journal of Service Research, 15(4), 430-442.

Holmqvist, J., Van Vaerenbergh, Y., \& Grönroos, C. (2017). Language use in services: Recent advances and directions for future research. Journal of Business Research, 72, 114-118.

Huang, S.S. \& Crotts, J. (2019). Relationships between Hofstede's cultural dimensions and tourist satisfaction: A cross-country cross-sample examination, Tourism Management, 72, 232-241.

Huang, L., Zalkikar, J., Tiwari, R.C (2011). A likelihood ratio test based method for signal detection with application to FDA's drug safety data, Journal of the American Statistical Association, 106(496), 1230-1241.

Knight Frank. (2017). UK Hotel. Development Opportunities 2017. Retrieved August 2, 2017, from https://kfcontent.blob.core.windows.net/research/1264/documents/en/2017-4679.pdf

Kogut, B., \& Singh, H. (1988). The effect of national culture on the choice of entry mode. Journal of International Business Studies, 19(3), 411-432.

Lass, P. \& Hart, S. (2004). National cultures, values and lifestyle influencing consumers' perception towards sexual imagery in alcohol advertising: an exploratory study in the UK, Germany and Italy. Journal of Marketing Management, 20, 607-623.

Lenihan, A. (2011). Join our community of translators": Language ideologies and Facebook. Digital Discourse: Language in the New Media, 48-64.

Li, J., Xu, L., Tang, L., Wang, S., \& Li, L. (2018). Big data in tourism research: A literature review. Tourism Management, 68, 301-323.

Li M., Qiu S.C., Liu Z. (2016). The Chinese way of response to hospitality service failure: The effects of face and guanxi. International Journal of Hospitality Management, 57, 18-29.

Liu, Y., Teichert, T., Rossi, M., Li, H., \& Hu, F. (2017). Big data for big insights: Investigating language-specific drivers of hotel satisfaction with 412,784 user-generated reviews. Tourism Management, 59, 554-563.

Lynch, J.C., Bradlow, E.T., Huber, J.C., \& Lehmannd, D.R. (2015). Reflections on the replication corner: In praise of conceptual replications. International Journal of Research in Marketing, 32(4), 333-342.

Manzur, L., \& Jogaratnam, G. (2007). Impression management and the hospitality service encounter: cross-cultural differences. Journal of Travel \& Tourism Marketing, 20(3-4), 2132.

Mariani, M.M., Baggio, R., Buhalis, D., \& Longhi, C. (2014). Introduction. In Tourism Management, Marketing and Development: Volume I: the Importance of Networks and ICTs; Mariani, M.M., Baggio, R., Buhalis, D., Longhi, C., Eds.; Palgrave: New York, NY, USA, 2014; pp. 1-14. doi:10.1016/10.1057/9781137354358_1.

Mariani, M.M., Buhalis, D., Longhi, C., Vitouladiti, O. (2014). Managing change in tourism destinations: Key issues and current trends. Journal of Destination Marketing \& Management, 2, 269-272. doi:10.1016/j.jdmm.2013.11.003.

Mariani, M., Baggio, R., Fuchs, M. and Höepken, W. (2018). Business intelligence and big data in hospitality and tourism: a systematic literature review, International Journal of Contemporary Hospitality Management, 30(12), 35143554. https://doi.org/10.1108/IJCHM-07-2017-0461

Mariani, M.M., \& Borghi, M. (2018). Effects of the Booking. com rating system: Bringing hotel class into the picture. Tourism Management, 66, 47-52.

Mariani, M., Predvoditeleva, M. (2019). How do online reviewers' cultural traits and perceived experience influence hotel online ratings? An empirical analysis of the Muscovite hotel sector, International Journal of Contemporary Hospitality Management, 31(12), 45434573. https://doi.org/10.1108/IJCHM-11-2018-0927 
Mariani, M.M., Borghi, M., Gretzel, U. (2019). Online reviews: Differences by submission device, $\quad$ Tourism $\quad$ Management, $\quad 70, \quad 295-298$. https://doi.org/10.1016/j.tourman.2018.08.022

Mariani, M.M., Borghi, M., \& Kazakov, S. (2019). The role of language in the online evaluation of hospitality service encounters: An empirical study. International Journal of Hospitality Management, 78, 50-58.

Mariani, M.M., Di Fatta, G., Di Felice, M. (2019). Understanding Customer Satisfaction with Services by leveraging Big Data: the Role of Services Attributes and Consumers' Cultural Background, IEEE Access, 7,8580523, pp. 8195-8208, https://doi.org/10.1109/ACCESS.2018.2887300.

Mariani, M. (2019). Big Data and analytics in tourism and hospitality: a perspective article, Tourism Review, 75(1), 299-303. https://doi.org/10.1108/TR-06-2019-0259

Mariani, M. (2020). Web 2.0 and destination marketing: Current trends and future directions, Sustainability, 12(9), 3771.

Martinet, A. (1969). Elements of general linguistics. London: Faber and Faber.

Mattila, A.S. (1999). The role of culture and purchase motivation in service encounter evaluations. Journal of Services Marketing, 13, 376-389.

Mattila, A.S. (2000). The impact of culture and gender on customer evaluations of service encounters. Journal of Hospitality \& Tourism Research, 24(2), 263-273.

Mattila, A.S. (2001). The impact of relationship type on customer loyalty in a context of service failures. Journal of Service Research, 4(2), 91-101.

Mazanec, J.A., Crotts, J.C., Gursoy, D., \& Lu, L. (2015). Homogeneity versus heterogeneity of cultural values: An item-response theoretical approach applying Hofstede's cultural dimensions in a single nation. Tourism Management, 48, 299-304.

McSweeney, B. (2002). The Essentials of Scholarship: A Reply to Geert Hofstede. Human Relations, 55(11), 1363-1372.

Mok, C., \& Armstrong, R.W. (1998). Expectations for hotel service quality: do they differ from culture to culture? Journal of Vacation Marketing, 4(4), 381-391.

Morrison, A. 2019. Marketing and Managing Tourism Destinaitions. New York: Routledge.

Nath, P., Devlin, J., \& Reid, V. (2018). The effects of online reviews on service expectations: Do cultural value orientations matter? Journal of Business Research, 90, 123-133.

Pigni, F., Piccoli, G. \& Watson, R. (2016). Digital Data Streams: Creating value from the real-time flow of big data. California Management Review, 58(3), 5-25

Reisinger, Y., \& Crotts, J. (2010). Applying Hofstede's national culture measures in tourism research: Illuminating issues of divergence and convergence, Journal of Travel Research, 49(2), 153-164.

Reisinger, Y., \& Turner, L. (1999). A cultural analysis of Japanese tourists: challenges for tourism marketers. European Journal of Marketing, 33(11/12), 1203-1227.

Sainaghi, R., Phillips, P., \& Corti, V. (2013). Measuring hotel performance: Using a balanced scorecard perspectives' approach. International Journal of Hospitality Management, 34, 150 159.

Schmitt, B. \& Pan, Y. (1994). Managing Corporate and Brand Identities in the Asia-Pacific Region, California Management Review, 36, 32-48.

Schuckert, M., Liu, X., \& Law, R. (2015). A segmentation of online reviews by language groups: How English and non-English speakers rate hotels differently. International Journal of Hospitality Management, 48, 143-149.

Shama, A. (1994). Transformation of marketing management in Russia: A qualitative and theory building approach. Thunderbird International Business Review, 36 (5), 599-624

Shostack, L.G. (1977). Breaking free from product marketing. The Journal of Marketing, 73-80.

Shostack, L.G. (1985). Planning the service encounter. The Service Encounter.

Silverstein, M. (2004). 'Cultural' Concepts and the Language-Culture Nexus. Current Anthropology, 45(5), 621-652.

Sparks, B.A., \& Browning, V. (2011). The impact of online reviews on hotel booking intentions 
and perception of trust. Tourism Management, 32(6), 1310-1323.

Sparks, B.A., \& Callan, V.J. (1992). Communication and the service encounter: The value of convergence. International Journal of Hospitality Management, 11(3), 213-224.

Stamolampros, P., Korfiatis, N., Kourouthanassis, P., \& Symitsi, E. (2019). Flying to quality: Cultural influences on online reviews. Journal of Travel Research, 58(3), 496-511.

Sultan, F., \& Simpson, M.C. (2000). International service variants: airline passenger expectations and perceptions of service quality, Journal of Services Marketing, 14(3), 188-216.

UNWTO. (2019). World Tourism Barometer, 17(1). Retrieved February 2, 2019, from http://cf.cdn.unwto.org/sites/all/files/pdf/unwto_barom19_01_january_excerpt.pdf

Van der Laan, M., Hsu, J-P. and Rose, S. (2010). Statistics Ready for a Revolution. Next Generation of Statisticians Must Build Tools for Massive Data Sets. AMSTAT NEWS, September, Available: https://magazine.amstat.org/blog/2010/09/01/statrevolution/.

Vargo, S.L., \& Lusch, R.F. (2004). Evolving to a new dominant logic for marketing. Journal of Marketing, 68(1), 1-17.

Wagner, R. (2005). Contemporary marketing practices in Russia. European Journal of Marketing, 39(1/2), 199-215.

Wang, C.-Y., Miao, L., \& Mattila, A.S. (2015). Customer responses to intercultural communication accommodation strategies in hospitality service encounters. International Journal of Hospitality Management, 51, 96-104.

Yu, L. \& Siong Huat, G. (1995). Perceptions of management difficulty factors by expatriate hotel professionals in China, International Journal of Hospitality Management, 14, 375-388.

Zeithaml, V.A., Berry, L.L., \& Parasuraman, A. (1996). The behavioral consequences of service quality. The Journal of Marketing, 31-46.

Zhang, C., Laroche, M., \& Richard, M.O. (2017). The differential roles of verbs, nouns, and adjectives in English and Chinese messages among bilingual consumers. Journal of Business Research, 72, 127-135. 
Figure 1.a-Top 5 countries of origin, Rome

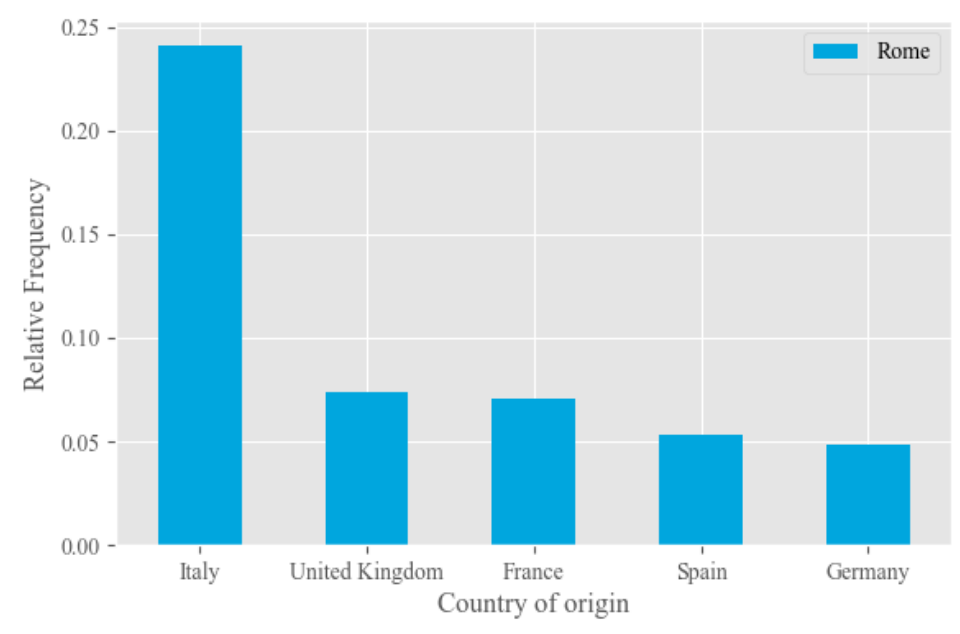

Figure 1.b - Top 5 countries of origin, Moscow

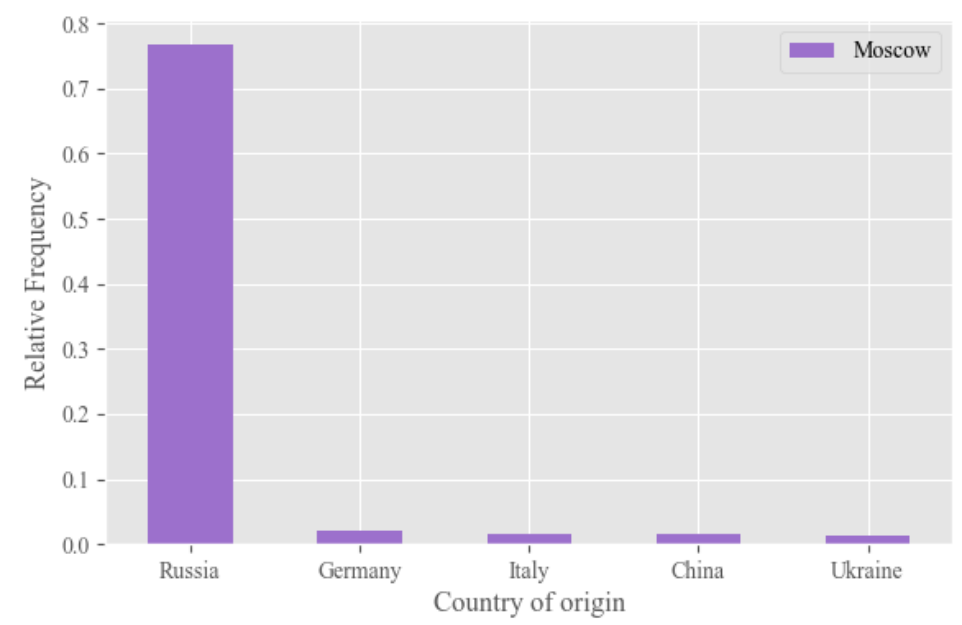

Figure 1.c - Top 5 countries of origin, London

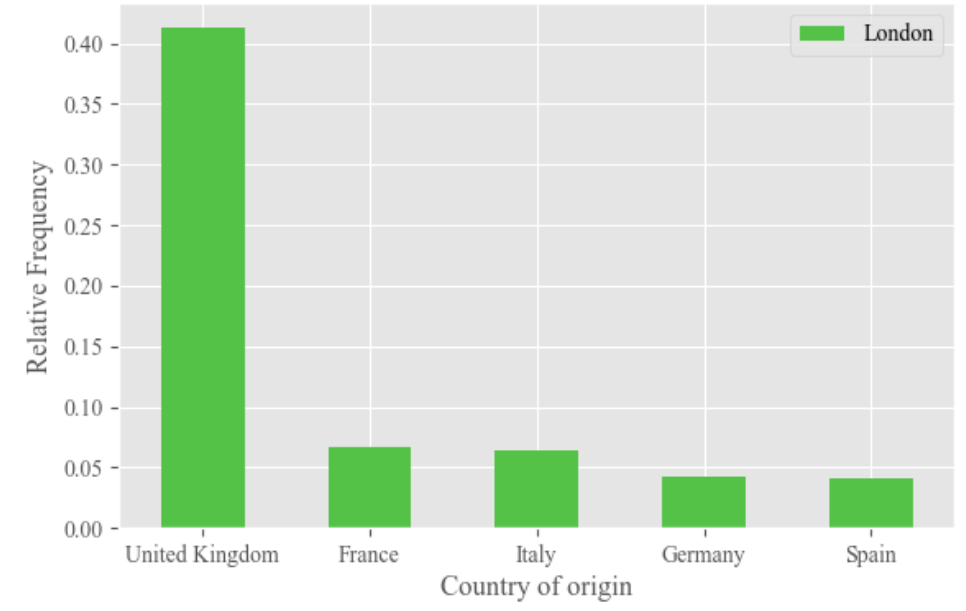


Figure 2.a - Top 5 languages, Rome

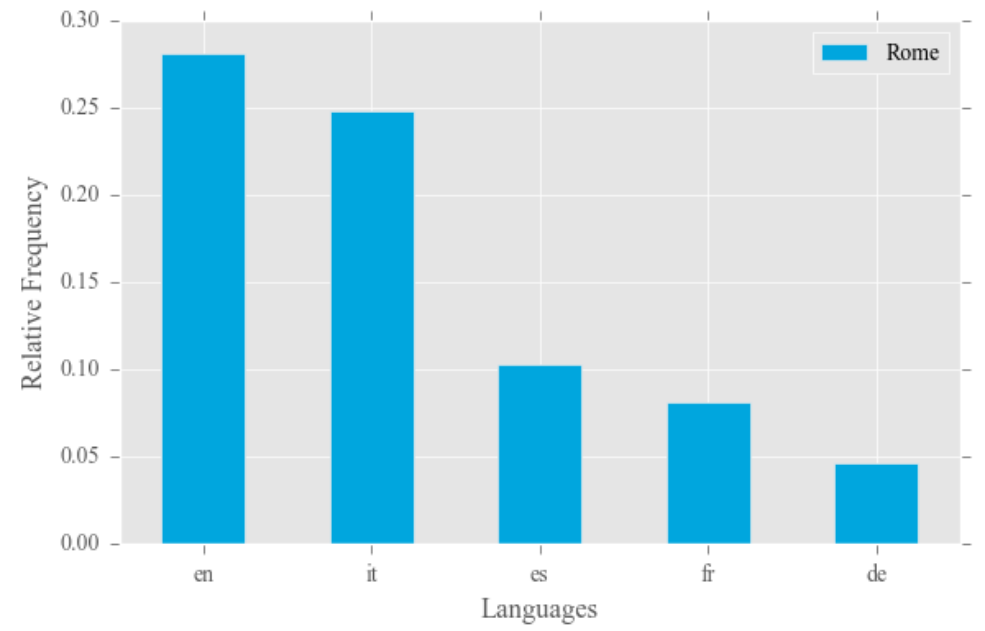

Figure 2.b - Top 5 languages, Moscow

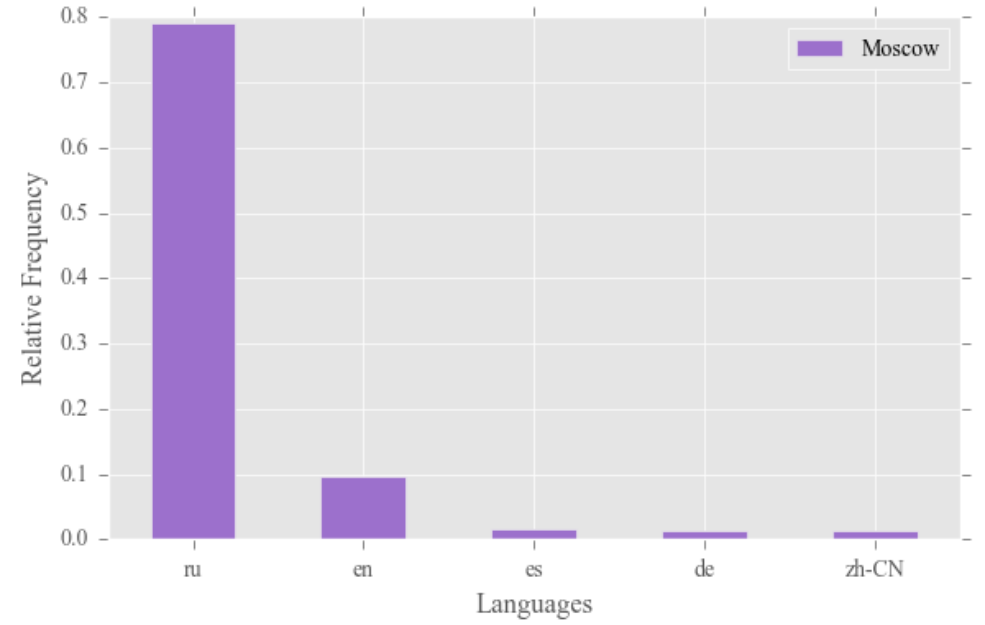

Figure 2.c - Top 5 languages, London

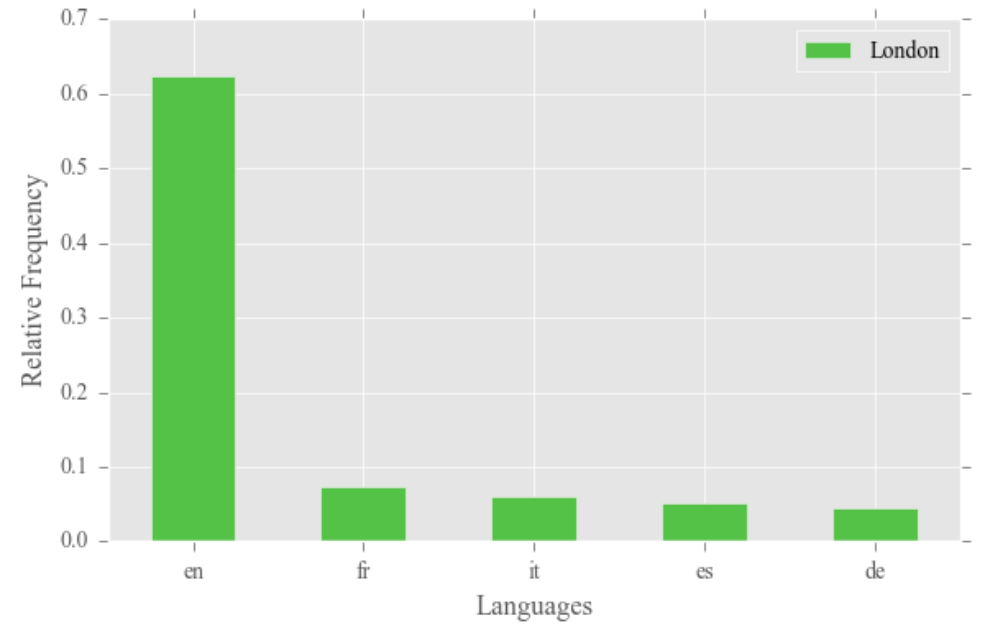


Figure 3 - Hofstede cultural dimensions in the three countries under consideration

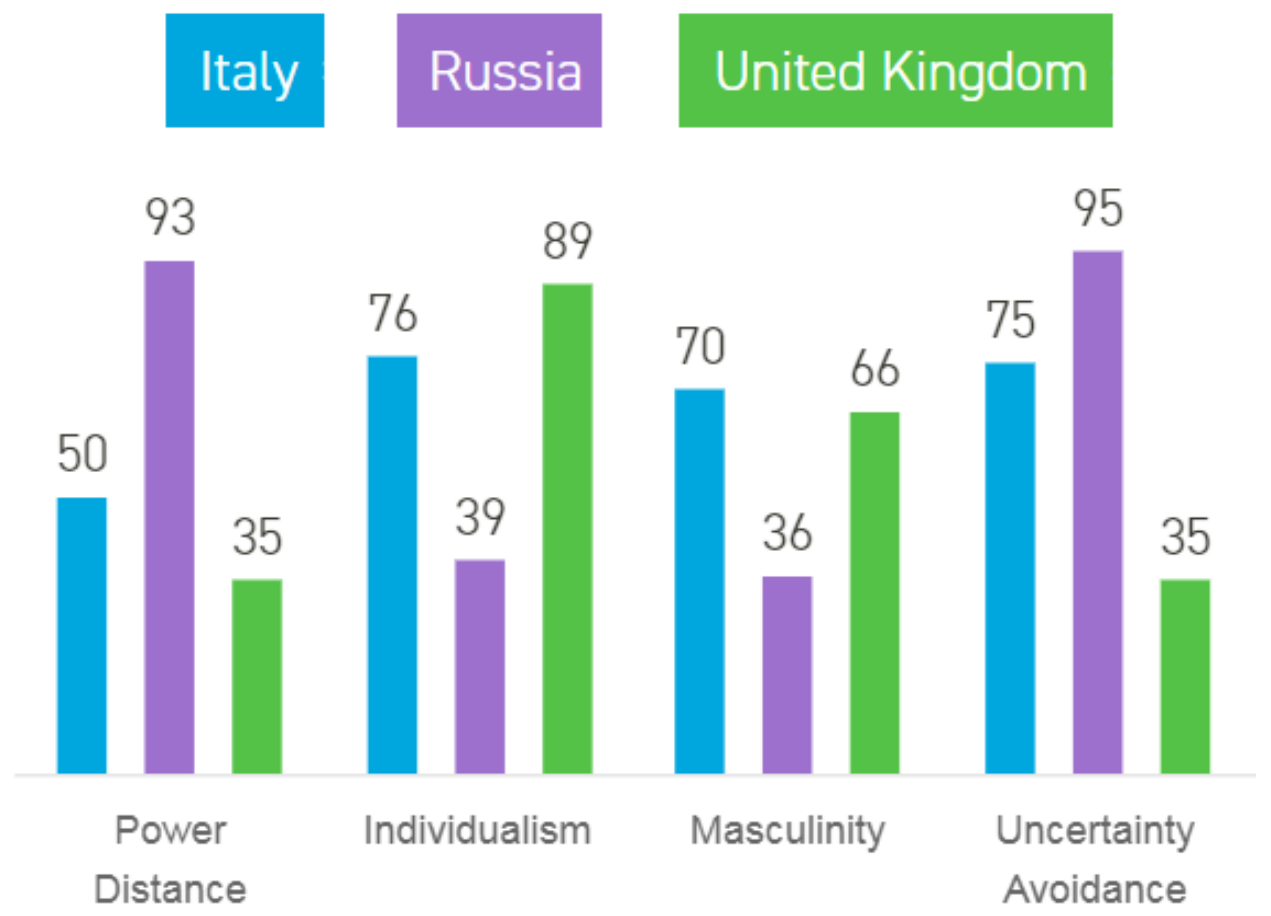

Source: https://www.hofstede-insights.com/product/compare-countries/ 
Table 1 - Hofstede dimensions' definitions

\begin{tabular}{|c|c|}
\hline Hofstede Dimension & Description \\
\hline Power distance & $\begin{array}{l}\text { "extent to which the less powerful members of } \\
\text { organizations and institutions (like the family) accept } \\
\text { and expect that power is distributed unequally" (Hofstede, } \\
\text { 2011: p.9) }\end{array}$ \\
\hline Individualism & $\begin{array}{l}\text { "degree to which people in a society are integrated } \\
\text { into groups" (Hofstede, 2011: p.11) }\end{array}$ \\
\hline Masculinity & $\begin{array}{l}\text { "to the distribution of values between the genders" } \\
\text { (Hofstede, 2011: p.12) }\end{array}$ \\
\hline Uncertainty Avoidance & $\begin{array}{l}\text { "to what extent a culture programs its members to feel } \\
\text { either uncomfortable or comfortable in unstructured } \\
\text { situations" (Hofstede, 2011: p. 12) }\end{array}$ \\
\hline Long-term orientation & $\begin{array}{l}\text { "perseverance, thrift, ordering relationships by status, and } \\
\text { having a sense of shame" (Hofstede, 2011: p.13) }\end{array}$ \\
\hline Indulgence & $\begin{array}{l}\text { "relatively free gratification of basic and natural human } \\
\text { desires related to enjoying life and having fun" (Hofstede, } \\
\text { 2011: p.15) }\end{array}$ \\
\hline
\end{tabular}


Table 2 - Pattern in the Booking.com data retrieved

\begin{tabular}{|l|c|c|c|}
\hline Destination & $\begin{array}{c}\text { \% Leisure tourists } \\
\text { Booking.com }\end{array}$ & $\begin{array}{c}\text { \% International tourists } \\
\text { Booking.com }\end{array}$ & $\begin{array}{c}\text { \% International tourists } \\
\text { (official statistics) }\end{array}$ \\
\hline Rome & $83.4 \%$ & $69 \%$ & $72.1 \%$ \\
\hline London & $82.5 \%$ & $60.7 \%$ & $77.6 \%$ \\
\hline Moscow & $52.0 \%$ & $24.9 \%$ & $31.3 \%$ \\
\hline
\end{tabular}


Table 3 - Hofstede's scores for the selected destinations

\begin{tabular}{|l|c|c|c|c|}
\hline Country & Power Distance & Individualism & Masculinity & Uncertainty Avoidance \\
\hline Italy & 50 & 76 & 70 & 75 \\
\hline Russia & 93 & 39 & 36 & 95 \\
\hline United Kingdom & 35 & 89 & 66 & 35 \\
\hline
\end{tabular}


Table 4 - Cross tabulation of travelers' origin in the three destinations

\begin{tabular}{c|c|c|c|}
\multirow{2}{*}{ Destination } & \multicolumn{2}{|c|}{ Traveler's Location } & \\
& International & Domestic & Total \\
\hline \multirow{2}{*}{ London } & 419,562 & 295,274 & 714,836 \\
& $58.69 \%$ & $41.31 \%$ & $100 \%$ \\
& & & \\
\hline \multirow{2}{*}{ Moscow } & 38,178 & 125,896 & 164,074 \\
& $23.27 \%$ & $76.73 \%$ & $100 \%$ \\
& & & \\
\hline \multirow{2}{*}{ Rome } & 253,064 & 80,307 & 333,371 \\
& $75.91 \%$ & $24.09 \%$ & $100 \%$ \\
& & & \\
\hline \multirow{2}{*}{ Total } & 710,804 & 501,477 & $1,212,281$ \\
& $58.63 \%$ & $41.37 \%$ & $100 \%$ \\
\hline
\end{tabular}


Table 5 - Variables description

\begin{tabular}{|l|l|}
\hline \multicolumn{1}{|c|}{ Variable } & \multicolumn{1}{|c|}{ Description } \\
\hline Rating & Online rating posted by a reviewer \\
\hline $\begin{array}{l}\text { Cultural Distance } \\
\text { (Cultural_Distance) }\end{array}$ & $\begin{array}{l}\text { The cultural distance between a hotel guest and a hotel's country } \\
\text { of origin measured embedding the Hofstede cultural dimensions } \\
\text { into the metric used by Kogut and Singh (1988) }\end{array}$ \\
\hline $\begin{array}{l}\text { Domestic Language } \\
\text { (Language) }\end{array}$ & $\begin{array}{l}\text { The language used to write a review. It is a dummy variable } \\
\text { whose value is } 1 \text { if the language used is the domestic language } \\
\text { of the country/destination where the hotel is located (i.e., Italian } \\
\text { for Rome, Russian for Moscow and English for London), and } \\
\text { zero otherwise }\end{array}$ \\
\hline $\begin{array}{l}\text { Observed Average Rating } \\
\text { (Obs_Avg_Rating) }\end{array}$ & $\begin{array}{l}\text { Hotels' review average rating as observed by the reviewing } \\
\text { guest at the time when s/he posted his/her review (see Gao et al., } \\
\text { 2018) }\end{array}$ \\
\hline $\begin{array}{l}\text { No Identity Disclosure } \\
\text { (No_Identity_Disc) }\end{array}$ & $\begin{array}{l}\text { It is a dummy variable that is equal to } 1 \text { if the reviewer did not } \\
\text { disclose her/his gender and age, and zero otherwise } \\
\text { (see Gao et al., 2018) }\end{array}$ \\
\hline $\begin{array}{l}\text { Gender* } \\
\text { (Female) }\end{array}$ & $\begin{array}{l}\text { It is a dummy variable that is equal to } 1 \text { if a reviewer's gender is } \\
\text { female, and zero otherwise }\end{array}$ \\
\hline $\begin{array}{l}\text { Length of Stay } \\
\text { (LoS) }\end{array}$ & Number of nights spent in the hotel by the reviewer \\
\hline $\begin{array}{l}\text { Solo Traveler } \\
\text { (Solo) }\end{array}$ & $\begin{array}{l}\text { It is a dummy variable that is equal to } 1 \text { if a reviewer is } \\
\text { travelling solo, and zero otherwise }\end{array}$ \\
\hline Irip Purpose & travelling for leisure, and zero otherwise \\
\hline
\end{tabular}

* The declared name of the reviewer was deployed to infer, through the Python library genderize.io (https://genderize.io/). 
Table 6.a - Descriptive statistics, Rome

\begin{tabular}{lcccc}
\hline & Mean & SD & Min & Max \\
\hline Rating & 8.12 & 1.66 & 2.50 & 10.00 \\
Cultural_distance & 1.44 & 1.06 & 0.23 & 4.89 \\
Language & 0.01 & 0.09 & 0.00 & 1.00 \\
Obs_Avg_Rating & 8.13 & 0.67 & 4.40 & 10.00 \\
badge_dummy & 0.42 & 0.49 & 0.00 & 1.00 \\
No_Identity_Disc & 0.16 & 0.37 & 0.00 & 1.00 \\
Female & 0.37 & 0.48 & 0.00 & 1.00 \\
LoS & 3.20 & 1.60 & 1.00 & 28.00 \\
Solo & 0.12 & 0.33 & 0.00 & 1.00 \\
Leisure & 0.95 & 0.21 & 0.00 & 1.00 \\
\hline Observations & 253,064 & & & \\
\hline
\end{tabular}

Table 6.b - Descriptive statistics, Moscow

\begin{tabular}{lcccc}
\hline & Mean & SD & Min & Max \\
\hline Rating & 8.17 & 1.70 & 2.50 & 10.00 \\
Cultural_distance & 2.56 & 1.69 & 0.08 & 7.00 \\
Language & 0.21 & 0.41 & 0.00 & 1.00 \\
Obs_Avg_Rating & 8.28 & 0.63 & 4.60 & 9.90 \\
badge_dummy & 0.52 & 0.50 & 0.00 & 1.00 \\
No_Identity_Disc & 0.18 & 0.38 & 0.00 & 1.00 \\
Female & 0.28 & 0.45 & 0.00 & 1.00 \\
LoS & 3.18 & 2.18 & 1.00 & 35.00 \\
Solo & 0.41 & 0.49 & 0.00 & 1.00 \\
Leisure & 0.67 & 0.47 & 0.00 & 1.00 \\
\hline Observations & 38,178 & & & \\
\hline
\end{tabular}

Table 6.c - Descriptive statistics, London

\begin{tabular}{lcccc}
\hline & Mean & SD & Min & Max \\
\hline Rating & 7.60 & 1.80 & 2.50 & 10.00 \\
Cultural_distance & 2.26 & 1.55 & 0.09 & 8.58 \\
Language & 0.37 & 0.48 & 0.00 & 1.00 \\
Obs_Avg_Rating & 7.79 & 0.90 & 3.60 & 9.90 \\
badge_dummy & 0.36 & 0.48 & 0.00 & 1.00 \\
No_Identity_Disc & 0.17 & 0.38 & 0.00 & 1.00 \\
Female & 0.39 & 0.49 & 0.00 & 1.00 \\
LoS & 3.05 & 1.82 & 1.00 & 31.00 \\
Solo & 0.21 & 0.41 & 0.00 & 1.00 \\
Leisure & 0.86 & 0.34 & 0.00 & 1.00 \\
\hline Observations & 419,562 & & & \\
\hline
\end{tabular}


Table 7 - Effect of cultural distance and language on OR ratings

\begin{tabular}{|c|c|c|c|}
\hline & $\begin{array}{c}\text { (1) } \\
\text { London }\end{array}$ & $\begin{array}{c}(2) \\
\text { Moscow }\end{array}$ & $\begin{array}{c}(3) \\
\text { Rome }\end{array}$ \\
\hline Language & $\begin{array}{c}0.138^{* * *} \\
(0.00564)\end{array}$ & $\begin{array}{l}0.397^{* * *} \\
(0.0248)\end{array}$ & $\begin{array}{c}0.0752^{*} \\
(0.0380)\end{array}$ \\
\hline Cultural_distance & $\begin{array}{l}-0.0286^{* * *} \\
(0.00173)\end{array}$ & $\begin{array}{l}0.0505^{* * *} \\
(0.00572)\end{array}$ & $\begin{array}{l}-0.0334^{* * * *} \\
(0.00333)\end{array}$ \\
\hline Obs_Avg_Rating & $\begin{array}{c}1.141^{* * *} \\
(0.00352)\end{array}$ & $\begin{array}{l}1.198^{* * *} \\
(0.0171)\end{array}$ & $\begin{array}{c}1.180^{* * *} \\
(0.00551)\end{array}$ \\
\hline No_Identity_Disc & $\begin{array}{l}-0.160^{* * * *} \\
(0.00736)\end{array}$ & $\begin{array}{c}-0.176^{* * * *} \\
(0.0260)\end{array}$ & $\begin{array}{c}-0.228^{* * * *} \\
(0.0101)\end{array}$ \\
\hline Female & $\begin{array}{c}0.201^{\text {***' }} \\
(0.00580)\end{array}$ & $\begin{array}{l}0.131^{* * * *} \\
(0.0225)\end{array}$ & $\begin{array}{c}0.169^{* * *} \\
(0.00775)\end{array}$ \\
\hline LoS & $\begin{array}{l}0.0211^{* * * *} \\
(0.00146)\end{array}$ & $\begin{array}{c}0.0114^{* * *} \\
(0.00441)\end{array}$ & $\begin{array}{l}0.0136^{* * *} \\
(0.00221)\end{array}$ \\
\hline Solo & $\begin{array}{c}0.0247^{* *} \\
(0.00756)\end{array}$ & $\begin{array}{c}-0.00643 \\
(0.0224)\end{array}$ & $\begin{array}{c}0.0693^{* * *} \\
(0.0114)\end{array}$ \\
\hline Leisure & $\begin{array}{c}0.436^{* * *} \\
(0.00895)\end{array}$ & $\begin{array}{c}0.490^{* * * *} \\
(0.0239)\end{array}$ & $\begin{array}{l}0.378^{* * * *} \\
(0.0179)\end{array}$ \\
\hline Constant & $\begin{array}{l}-1.682^{* * * *} \\
(0.0305)\end{array}$ & $\begin{array}{c}-2.271^{* * * *} \\
(0.148)\end{array}$ & $\begin{array}{c}-1.590^{* * * *} \\
(0.0594)\end{array}$ \\
\hline $\begin{array}{r}\text { Company controls } \\
\text { Hotel star rating } \\
\text { Chain }\end{array}$ & $\begin{array}{l}\text { YES } \\
\text { YES }\end{array}$ & $\begin{array}{l}\text { YES } \\
\text { YES }\end{array}$ & $\begin{array}{l}\text { YES } \\
\text { YES }\end{array}$ \\
\hline $\begin{array}{l}\text { Observations } \\
\text { AIC } \\
\text { LR Chi2 } \\
\text { Log Likelihood } \\
\text { Pseudo } R^{2}\end{array}$ & $\begin{array}{c}419,562 \\
1,544,407.2 \\
133,608.1^{* * *} \\
-772,188.6 \\
7.96 \%\end{array}$ & $\begin{array}{c}38,178 \\
138,782.4 \\
7,443.3^{* * * *} \\
-69,376.2 \\
5.09 \%\end{array}$ & $\begin{array}{c}253,064 \\
915,218.2 \\
48,717.7^{* * *} \\
-457,594.1 \\
5.05 \%\end{array}$ \\
\hline
\end{tabular}

Standard errors in parentheses

${ }^{*} p<0.05,{ }^{* *} p<0.01,{ }^{* * *} p<0.001$ 
Table 8 - Robustness checks using only ORs written in 2015

\begin{tabular}{|c|c|c|c|}
\hline & $\begin{array}{c}(1) \\
\text { London }\end{array}$ & $\begin{array}{c}(2) \\
\text { Moscow }\end{array}$ & $\begin{array}{c}(3) \\
\text { Rome }\end{array}$ \\
\hline Language & $\begin{array}{c}0.138^{* * *} \\
(0.00835)\end{array}$ & $\begin{array}{l}0.355^{* * *} \\
(0.0414)\end{array}$ & $\begin{array}{c}0.151^{*} \\
(0.0610)\end{array}$ \\
\hline Cultural_distance & $\begin{array}{l}-0.0272^{* * *} \\
(0.00256)\end{array}$ & $\begin{array}{l}0.0601^{* * *} \\
(0.00893)\end{array}$ & $\begin{array}{c}-0.0429^{* * * *} \\
(0.00501)\end{array}$ \\
\hline Obs_Avg_Rating & $\begin{array}{l}1.154^{* * *} \\
(0.00530)\end{array}$ & $\begin{array}{l}1.218^{* * *} \\
(0.0273)\end{array}$ & $\begin{array}{c}1.130^{* * *} \\
(0.00826)\end{array}$ \\
\hline No_Identity_Disc & $\begin{array}{c}-0.158^{* * *} \\
(0.0103)\end{array}$ & $\begin{array}{l}-0.221^{* * * *} \\
(0.0395)\end{array}$ & $\begin{array}{c}-0.250^{* * * *} \\
(0.0146)\end{array}$ \\
\hline Female & $\begin{array}{c}0.207^{* * *} \\
(0.00884)\end{array}$ & $\begin{array}{l}0.161^{* * * *} \\
(0.0372)\end{array}$ & $\begin{array}{l}0.186^{* * *} \\
(0.0120)\end{array}$ \\
\hline LoS & $\begin{array}{l}0.0282^{* * * *} \\
(0.00218)\end{array}$ & $\begin{array}{c}0.00796 \\
(0.00752)\end{array}$ & $\begin{array}{l}0.0121^{* * * *} \\
(0.00337)\end{array}$ \\
\hline Solo & $\begin{array}{c}0.0182 \\
(0.0112)\end{array}$ & $\begin{array}{l}-0.0113 \\
(0.0357)\end{array}$ & $\begin{array}{c}0.0366^{*} \\
(0.0178)\end{array}$ \\
\hline Leisure & $\begin{array}{l}0.444^{* * *} \\
(0.0131)\end{array}$ & $\begin{array}{l}0.502^{* * *} \\
(0.0380)\end{array}$ & $\begin{array}{l}0.409^{* * *} \\
(0.0279)\end{array}$ \\
\hline Constant & $\begin{array}{l}-1.824^{* * *} \\
(0.0459)\end{array}$ & $\begin{array}{c}-2.491^{* * *} \\
(0.239)\end{array}$ & $\begin{array}{c}-1.243^{* * *} \\
(0.0883)\end{array}$ \\
\hline $\begin{array}{r}\text { Company controls } \\
\text { Hotel star rating } \\
\text { Chain }\end{array}$ & $\begin{array}{l}\text { YES } \\
\text { YES }\end{array}$ & $\begin{array}{l}\text { YES } \\
\text { YES }\end{array}$ & $\begin{array}{l}\text { YES } \\
\text { YES }\end{array}$ \\
\hline $\begin{array}{l}\text { Observations } \\
\text { AIC } \\
\text { LR Chi2 } \\
\text { Log Likelihood } \\
\text { Pseudo } R^{2} \\
\end{array}$ & $\begin{array}{c}185,234 \\
680,892.8 \\
60,872.2^{* * *} \\
-340,431.4 \\
8.21 \% \\
\end{array}$ & $\begin{array}{c}14,695 \\
53,751.5 \\
2,897.4^{* * *} \\
-26,860.7 \\
5.12 \% \\
\end{array}$ & $\begin{array}{c}106,472 \\
384,791.7 \\
20,117.4^{* * *} \\
-192,380.9 \\
4.97 \% \\
\end{array}$ \\
\hline
\end{tabular}

Standard errors in parentheses

${ }^{*} p<0.05,{ }^{* *} p<0.01,{ }^{* * *} p<0.001$ 
Table 9 - Robustness checks using only ORs written in 2016

\begin{tabular}{|c|c|c|c|}
\hline & $\begin{array}{c}(1) \\
\text { London }\end{array}$ & $\begin{array}{c}(2) \\
\text { Moscow }\end{array}$ & $\begin{array}{c}(3) \\
\text { Rome }\end{array}$ \\
\hline Language & $\begin{array}{c}0.138^{* * *} \\
(0.00772)\end{array}$ & $\begin{array}{l}0.390^{* * *} \\
(0.0329)\end{array}$ & $\begin{array}{c}0.0610^{*} \\
(0.0275)\end{array}$ \\
\hline Cultural_distance & $\begin{array}{l}-0.0301^{\text {*** }} \\
(0.00235)\end{array}$ & $\begin{array}{l}0.0439^{* * *} \\
(0.00780)\end{array}$ & $\begin{array}{c}-0.0307^{* * * *} \\
(0.00466)\end{array}$ \\
\hline Obs_Avg_Rating & $\begin{array}{l}1.131^{* * * *} \\
(0.00475)\end{array}$ & $\begin{array}{l}1.178^{* * *} \\
(0.0230)\end{array}$ & $\begin{array}{c}1.213^{* * *} \\
(0.00780)\end{array}$ \\
\hline No_Identity_Disc & $\begin{array}{c}-0.148^{* * *} \\
(0.0106)\end{array}$ & $\begin{array}{c}-0.141^{* * * *} \\
(0.0360)\end{array}$ & $\begin{array}{c}-0.210^{* * * *} \\
(0.0149)\end{array}$ \\
\hline Female & $\begin{array}{c}0.194^{* * *} \\
(0.00775)\end{array}$ & $\begin{array}{l}0.107^{* * * *} \\
(0.0296)\end{array}$ & $\begin{array}{l}0.154^{* * * *} \\
(0.0107)\end{array}$ \\
\hline LoS & $\begin{array}{l}0.0160^{* * * *} \\
(0.00197)\end{array}$ & $\begin{array}{c}0.0141^{*} \\
(0.00578)\end{array}$ & $\begin{array}{l}0.0151^{* * * *} \\
(0.00310)\end{array}$ \\
\hline Solo & $\begin{array}{l}0.0271^{\text {*** }} \\
(0.0103)\end{array}$ & $\begin{array}{l}-0.0206 \\
(0.0301)\end{array}$ & $\begin{array}{c}0.0620^{* * *} \\
(0.0162)\end{array}$ \\
\hline Leisure & $\begin{array}{l}0.426^{\text {*** }} \\
(0.0123)\end{array}$ & $\begin{array}{l}0.470^{* * *} \\
(0.0324)\end{array}$ & $\begin{array}{l}0.354^{* * *} \\
(0.0247)\end{array}$ \\
\hline Constant & $\begin{array}{c}-1.567^{* * * *} \\
(0.0411)\end{array}$ & $\begin{array}{c}-2.063^{* * * *} \\
(0.199)\end{array}$ & $\begin{array}{c}-1.243^{* * *} \\
(0.0883)\end{array}$ \\
\hline $\begin{array}{r}\text { Company controls } \\
\text { Hotel star rating } \\
\text { Chain }\end{array}$ & $\begin{array}{l}\text { YES } \\
\text { YES }\end{array}$ & $\begin{array}{l}\text { YES } \\
\text { YES }\end{array}$ & $\begin{array}{l}\text { YES } \\
\text { YES }\end{array}$ \\
\hline $\begin{array}{l}\text { Observations } \\
\text { AIC } \\
\text { LR Chi2 } \\
\text { Log Likelihood } \\
\text { Pseudo } R^{2} \\
\end{array}$ & $\begin{array}{c}230,176 \\
847,824.0 \\
71,569.0^{* * *} \\
-423,897.0 \\
7.78 \% \\
\end{array}$ & $\begin{array}{c}21,114 \\
76,393.4 \\
4,105.1^{* * *} \\
-38,181.7 \\
5.1 \% \\
\end{array}$ & $\begin{array}{c}131,610 \\
477,236.4 \\
25,733.5^{* * *} \\
-238,603.2 \\
5.12 \% \\
\end{array}$ \\
\hline
\end{tabular}

Standard errors in parentheses

${ }^{*} p<0.05,{ }^{* *} p<0.01,{ }^{* * *} p<0.001$ 
Table 10 - Robustness check for missing values (gender)

\begin{tabular}{|c|c|c|c|}
\hline & $\begin{array}{c}\text { (1) } \\
\text { London }\end{array}$ & $\begin{array}{c}(2) \\
\text { Moscow }\end{array}$ & $\begin{array}{c}(3) \\
\text { Rome }\end{array}$ \\
\hline Language & $\begin{array}{c}0.160^{* * *} \\
(0.00641)\end{array}$ & $\begin{array}{l}0.411^{* * * *} \\
(0.0282)\end{array}$ & $\begin{array}{c}0.0761^{*} \\
(0.0375)\end{array}$ \\
\hline Cultural_distance & $\begin{array}{l}-0.0356^{* * *} \\
(0.00195)\end{array}$ & $\begin{array}{l}0.0554^{* * * *} \\
(0.00646)\end{array}$ & $\begin{array}{l}-0.0396^{\text {**** }} \\
(0.00377)\end{array}$ \\
\hline Obs_Avg_Rating & $\begin{array}{c}1.147^{* * *} \\
(0.00398)\end{array}$ & $\begin{array}{l}1.219^{* * *} \\
(0.0198)\end{array}$ & $\begin{array}{c}1.186^{* * * *} \\
(0.00620)\end{array}$ \\
\hline No_Age_Disc & $\begin{array}{c}-0.0960^{\text {*** }} \\
(0.0102)\end{array}$ & $\begin{array}{c}-0.0223^{\text {**** }} \\
(0.00302)\end{array}$ & $\begin{array}{c}-0.0452^{\text {**** }} \\
(0.0129)\end{array}$ \\
\hline Female & $\begin{array}{c}0.211^{\text {**** }} \\
(0.00594)\end{array}$ & $\begin{array}{l}0.130^{* * *} \\
(0.0231)\end{array}$ & $\begin{array}{c}0.170^{* * *} \\
(0.00792)\end{array}$ \\
\hline LoS & $\begin{array}{l}0.0205^{\text {*** }} \\
(0.00165)\end{array}$ & $\begin{array}{c}0.0109^{*} \\
(0.00506)\end{array}$ & $\begin{array}{l}0.0145^{* * *} \\
(0.00247)\end{array}$ \\
\hline Solo & $\begin{array}{l}0.0373^{* * * *} \\
(0.00866)\end{array}$ & $\begin{array}{c}-0.00962 \\
(0.0259)\end{array}$ & $\begin{array}{c}0.0827^{* * * *} \\
(0.0129)\end{array}$ \\
\hline Leisure & $\begin{array}{l}0.454^{* * *} \\
(0.0103)\end{array}$ & $\begin{array}{l}0.524^{* * *} \\
(0.0277)\end{array}$ & $\begin{array}{l}0.374^{* * * *} \\
(0.0206)\end{array}$ \\
\hline Constant & $\begin{array}{c}-1.660^{* * * *} \\
(0.0359)\end{array}$ & $\begin{array}{c}-2.431^{* * * *} \\
(0.173)\end{array}$ & $\begin{array}{c}-1.584^{* * *} \\
(0.0678)\end{array}$ \\
\hline $\begin{array}{r}\text { Company controls } \\
\text { Hotel star rating } \\
\text { Chain }\end{array}$ & $\begin{array}{l}\text { YES } \\
\text { YES }\end{array}$ & $\begin{array}{l}\text { YES } \\
\text { YES }\end{array}$ & $\begin{array}{l}\text { YES } \\
\text { YES }\end{array}$ \\
\hline $\begin{array}{l}\text { Observations } \\
\text { AIC } \\
\text { LR Chi2 } \\
\text { Log Likelihood } \\
\text { Pseudo } R^{2} \\
\end{array}$ & $\begin{array}{c}332,076 \\
1,220,090.8 \\
104,967.7^{* * * *} \\
-610,030.4 \\
7.92 \% \\
\end{array}$ & $\begin{array}{c}28,978 \\
104,598.9 \\
5,703.3^{* * *} \\
-52,284.4 \\
5.07 \% \\
\end{array}$ & $\begin{array}{c}202,857 \\
729,575.8 \\
38,044.8^{* * *} \\
-364,772.9 \\
4.96 \% \\
\end{array}$ \\
\hline
\end{tabular}

Standard errors in parentheses

${ }^{*} p<0.05,{ }^{* *} p<0.01,{ }^{* * *} p<0.001$ 
Table 11 - Pairwise destination differences assessment

\begin{tabular}{|c|l|}
\hline \multirow{2}{*}{ Destinations Pairs } & Absolute differences in Hofstede's cultural dimensions \\
\hline Italy - Russia & $\sum|50-93|+|76-39|+|70-36|+|75-95|=134$ \\
\hline United Kingdom - Russia & $\sum|35-93|+|89-39|+|66-36|+|35-95|=198$ \\
\hline Italy - United Kingdom & $\sum|50-35|+|76-89|+|70-66|+|75-35|=72$ \\
\hline
\end{tabular}

